\title{
Serebral palsi tedavisinde ortopedik cerrahide yenilikler: Alt ekstremite
}

\section{Current and new trends in orthopedic surgery in the treatment of cerebral palsy: Lower extremity}

\author{
Cemil Yıldız \\ SBÜ Gülhane Tıp Fakültesi, Ortopedi ve Travmatoloji Ana Bilim Dalı, Ankara
}

\begin{abstract}
Serebral palside kuvvet-kolu disfonksiyonu nedeniyle oluşan alt ekstremitelerdeki kas-iskelet sistemi deformiteleri nörolojik patolojiye, tedavi zamanlamasına ve şekline göre değişik klinik tablolarla ortaya çıkabilir. Serebral palsili çocukların cerrahisinde gelişmiş analiz yöntemleriyle çok yönlü değerlendirme yapılarak bir tedavi algoritmasının hastaya özel olarak oluşturulması güncel olan yaklaşımdır. Adduktor tenotomi, psoas uzatma ve iliopsoas tenotomisi gibi koruyucu cerrahiler, medial-lateral hamstring uzatma, rektus femoris transferi, patellar tendon uzatma gibi kas tendon uzatma veya transfer ameliyatları, kısaltma, derotasyon, varizasyon gibi osteotomi ameliyatları, Dega pelvik osteotomisi, total kalça artroplastisi gibi rekonstrüktif cerrahiler içeren çok geniş ortopedik cerrahi seçenekler güncel olarak kullanılmaktadır. Ancak tedavi ortez uygulamaları ve rehabilitasyon gibi diğer seçenekler ile 'multimodal bütüncül olarak interdisipliner yaklaşım' la yapılmalıdır. Bir hedef çevresinde kavram oluşturduktan sonra buna yönelik bütüncül bir tedavinin parçası olarak alt ekstremite cerrahisi uygulandığında hasta/aile/ cerrah memnuniyeti daha da artmaktadır. Serebral palsili çocuk hastaların büyüme sürecinde, farklı klinik tabloların ortaya çıkacağı unutulmamalı ve basit ya da hafif serebral palsi hastası olmadığı hatırlanarak her hastanın gereksinimine uygun 'a la carte' yöntem seçilmelidir. Tanı ve tedavide kusursuz olmak artık günümüzde bir lüks olmaktan çıkmış, yeni gelişen teknolojilerin yardımıyla zorunluluk haline gelmiştir.
\end{abstract}

Anahtar sözcülkler: serebral palsi; spastik; kas-iskelet hastalığı; alt ekstremite; ortopedik tedavi
Musculoskeletal deformities in the lower extremities caused by lever-arm dysfunction in cerebral palsy may present with different clinical pictures depending on the neurological pathology, treatment timing and procedure. In the surgery of children with cerebral palsy, it is the current approach to create a patient-specific treatment algorithm by making a multifaceted all-around evaluation with advanced analysis methods. A wide variety of orthopedic surgery options including reconstructive surgeries are currently in use. Preventive surgeries such as adductor tenotomy, psoas lengthening and iliopsoas tenotomy, muscle tendon lengthening or transfer operations such as hamstring lengthening, rectus femoris transfer, patellar tendon advancement, osteotomy procedures such as shortening, derotation and varisation of proximal femur, reconstructive surgery such as Dega pelvic osteotomy and total hip arthroplasty. However, treatment should be done with a 'multimodal and holistic interdisciplinary approach' with other options such as orthotic applications and rehabilitation. Patient/family/surgeon satisfaction increases when lower extremity surgery is applied as part of a multimodal holistic treatment after creating a concept around a goal. It should not be forgotten that different clinical pictures will occur during the growth process of pediatric patients with cerebral palsy, and the 'a la carte' method should be chosen according to the needs of each patient, remembering that there is no simple or mild cerebral palsy patient. Being perfect in diagnosis and treatment has become a necessity with the help of new developing technologies, which are no longer a luxury.

Key words: cerebral palsy; spastic; bone muscle disease; lower extremity; orthopedic management

Spastik hemipleji, dipleji ve kuadriplejide ayak, diz ve kalça eklemlerini içeren alt ekstremite sorunları çok sık görülmektedir. Özellikle erken çocukluk döneminde alt ektsremite ve yürüme sorunları aileler ve dolayısıyla bizim için daha öncelikli hal almaktadır. Bu nedenle literatürde SP'de alt ekstremite cerrahisi ile ilgili birçok

- Illetişim adresi: Dr. Cemil Yıldız, SBÜ Gülhane Tıp Fakültesi, Ortopedi ve Travmatoloji Ana Bilim Dalı, Ankara

Tel: 0535 -6623535 e-mail: cemilyildiz@icloud.com

- Geliș tarihi: 8 Mart $2021 \quad$ Kabul tarihi: 21 Mart 2021 
çalışma bulunmaktadır. ${ }^{[1-35]}$ Yazarın kliniğinde SP'li hastalardaki alt ekstremite kas ve iskelet sorunlarında uzun yıllara dayanan olgu birikimi ve tedavi tecrübesi mevcuttur. ${ }^{[1-18]}$

SP'li hastaların standardize edilmesindeki yetersizlikler, etik sorunlar ve değerlendirme farklılıkları gibi birçok zorluklar nedeniyle kanıta dayalı güvenilirliği yüksek çalışmalar halen sınırlı sayıdadır.

Bu yazıda, SP'li hastalardaki alt ekstremite sorunlarındaki güncel ortopedik yaklaşımlarve literatürdeki yenilikler kısa başlıklar halinde özet olarak bildirilecektir.

\section{Sınıflandırma}

Yapılacak tedavi doğal seyri değiştirmelidir. SP'de alt ekstremite sorunlarının doğal seyrinde eğer hasta tedavi görmez veya tedaviyi aksatırsa hareketlilik seviyesinde ciddi kayıp ve geç dönemde ağrı ve eklem dejenerasyonları ortaya çıkar.

SP'de kuwvet kolu disfonksiyonu nedeniyle oluşan alt ekstremitelerdeki kas-iskelet sistemi deformiteleri nörolojik patolojiye, tedavi zamanlamasına ve şekline göre değişik klinik tablolarla karşımıza çıkabilir. Bu temel prensipler doğrultusunda çok farklı amaca yönelik ortopedik cerrahi endikasyonlar bulunmaktadır (Tablo 1). ${ }^{[1-39]}$

Her SP hastası diğerinden farklıdır. Her SP hastasına aynı özenle yaklaşılması gereklidir. Sık görülen hatalardan biri, hemiplejik ya da diplejik hareketli bir hastanın hafife alınarak bir tedavi planının oluşturulmasıdır. Tam zıt olarak kuadriplejik, yürüyemeyen 'Kaba Motor Fonksiyon Sınıflandırma Sistemi' (KMFSS) 'V' olan bir hastanın kompleks sorunlarının da yarar görmez diye daha az önemsenmesidir. 'Hastalık yok hasta vardır' sözü özellikle SP'li hastalar için bir tedavi planı oluştururken akılda bulundurulmalıdır.

\section{Bütüncül Yaklaşım}

'SP bir tanı değil, değerlendirmedir!' (Dr. Keith Braun). Diğer kas-iskelet sistemi hastalıkları ile karşılaştırdığımızda SP'li hastalarda bütüncül bir yaklaşım tedavi başarısını ve hasta/aile memnuniyetini artırmaktadır. Örneğin bir meniskopati hastasındaki tedavi yaklaşımı ile benzer bir şekilde SP diz fleksiyon kontraktürüne yaklaşııırsa, başarısız olma ve hasta memnuniyetini sağlayamama olasılığı yüksek olacaktır. ${ }^{[21]}$

\section{Kusursuz Cerrahi Planlama}

'Plansız ve hazırlamadan yapılan cerrahi sonrası oluşan başarısızlıkları tedavi etmek için ayrıntılı plan yapmak zorunda kalınabilir.' Ameliyat tekniğini çok iyi olarak uygulamak ve kusursuz bir ameliyat yapmak SP'de hasta-aile memnuniyetinin sağlanacağı anlamına gelmemelidir. SP'li hastaların cerrahisinde sürekli gelişen analiz yöntemleriyle çok yönlü değerlendirme yapılarak bir tedavi algoritmasının hastaya özel olarak oluşturulması güncel olan yaklaşımdır. ${ }^{[19-21]}$ Diğer hastalıkların tedavisi için de geçerli olan kusursuz olmak artık günümüzde bir lüks olmaktan çıkmış yeni gelişen teknolojilerin yardımıyla zorunluluk haline gelmiştir.

\section{Hastaya Özel 'Ismarlama' Cerrahi Tedavi}

SP bir şemsiye terimdir. Son yıllarda her SP'li hasta yeni değerlendirme yöntemleriyle kendi özelinde değerlendirilerek 'adeta bir terzinin ölçü alıp elbise dikmesi' gibi tedavi edilmeye çalışılmaktadır. Alt ekstremite cerrahisi içinde bu prensipler aynen geçerlidir. Örneğin ayrıntılı değerlendirme gerektiren hareketli SP'li hastalarda hareket analizi yöntemlerini kullanarak etkin tedavi planları oluşturulabilir.

\section{Tek Bir CORA (center of rotation of angulation) Yoktur!}

Ortopedik cerrahideki alışkanlık deformitenin en belirgin olduğu yerden (CORA, center of rotation of angulation) tedavinin planlanmasıdır. Ancak bu alışkanlık ile SP'li bir hastaya yaklaşım başarısızlık getirecektir. Örneğin günlük pratikte sık olarak görülen parmak ucu yürüyüş yakınması ile gelen diplejik SP'li bir çocukta deformitenin en belirgin olduğu ve hemen göze çarpan aşil tendonu kısalığı için bir uzatma cerrahisi yapıldığında erken dönemde plantigrad bir şekilde

Tablo 1. Serebral palside başlıca ortopedik cerrahi endikasyonlar

\begin{tabular}{ll}
\hline Kas-tendon veya tendon uzatma & - Fonksiyonu artırmak \\
Tendon transferleri & - Deformite gelişimini engellemek \\
- Osteotomiler & - Daha iyi yürüyüşü sağlamak \\
Artrodez & - Oturma dengesini oluşturmak \\
- Artroplasti & - Ağrıyı azaltmak \\
& - Hijyen \\
& - Yardımcı cihaz/ortez kullanımını sağlamak \\
& - Bakıcı desteğini kolaylaştırmak \\
& - Kozmetik
\end{tabular}




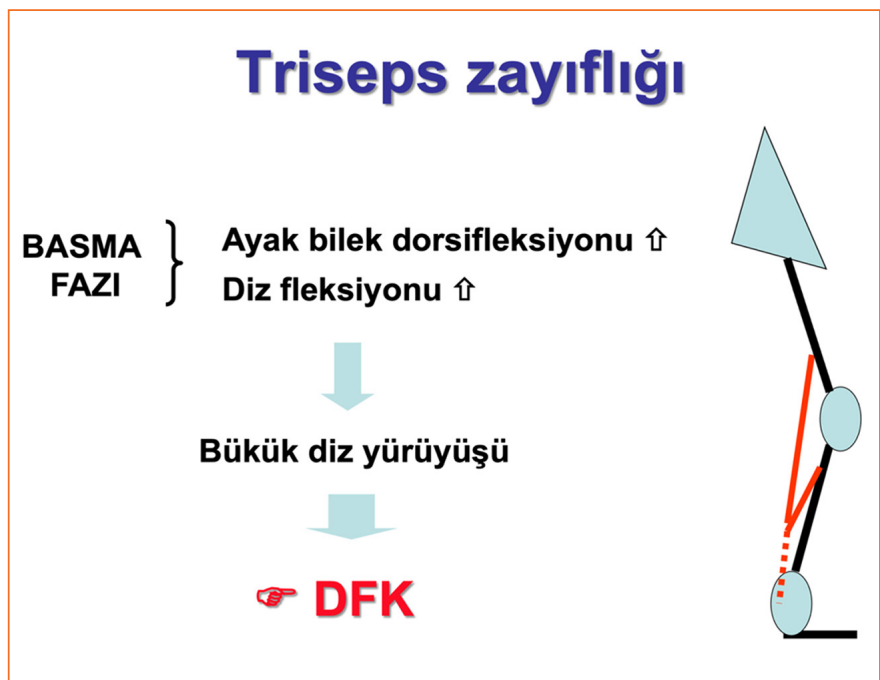

Şekil 1. İyatrojenik triseps zayıflığı bükük diz yürüyüşüne sebep olabilir. (DFK, diz fleksiyon kontraktürü)

basacak ancak bir süre sonra hasta bükük diz yürüyüşü ile gelebilecektir (Şekil 1). 'Dalış sendromu' denen bu durum geç takiplerde hastayı yürüyemez hale getirebilecektir (Şekil 2).

\section{İnterdisipliner Değerlendirme ve Tedavi}

Multidisipliner (Çok alanlı) çalışma zordur! Multidisipliner çalışma ile alınan kararlar hastanın takip ve tedavisinde başarıyı artıracaktır. Takım çalışmasının üyeleri rutin çalışma şartlarının zorluğunu aşıp başarılı tedavi için multidisipliner toplantıları yapmalıdırlar. Alt ekstremite cerrahisinde de interdisipliner (alanlar arası) yaklaşım hasta memnuniyetini artırır.

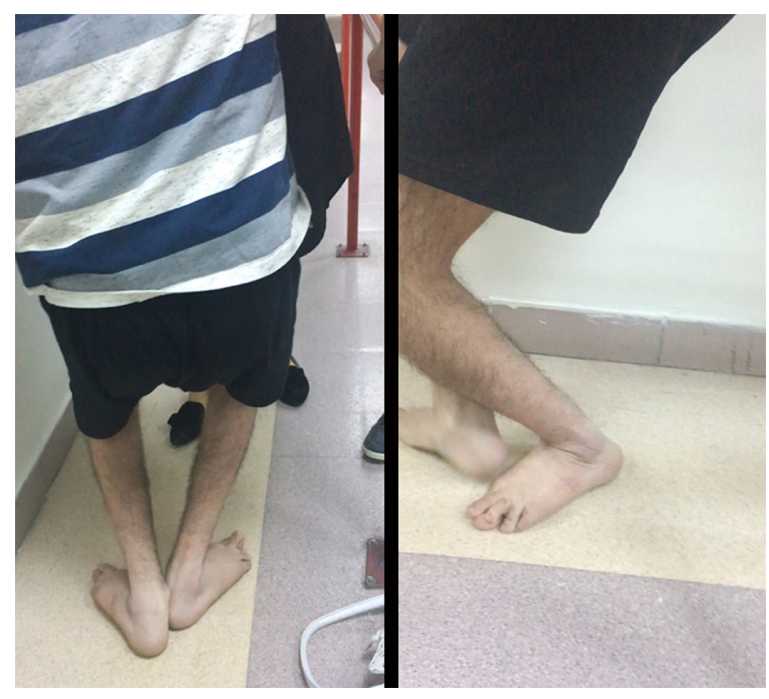

Şekil 2. Aşil tendonu uzatma cerrahisi sonrası ileri dönem takipte iyatrojenik bükük diz yürüyüşü gelişir ve hareketlilik seviyesi geriler.

\section{Hedefe Yönelik Multimodal Tedavi}

'SP özel bir hastalık olarak değil bir kavram fikir olarak değerlendirilmelidir' sözü (Dr. P Rosenbaum) SP'deki güncel bakış açısını özetlemektedir. Bir hedef çevresinde kavram oluşturduktan sonra buna yönelik bütünsel bir tedavinin parçası olarak alt ekstremite cerrahisi uygulandığında hasta/aile/cerrah memnuniyeti daha yüksek olmaktadır. Güncel pratikte eldeki tüm seçenekleri göz önünde bulundurarak cerrahiye karar verilmelidir (Tablo 2). ${ }^{[1-39]}$

Örneğin klinikte sık görülen üç yaşında parmak ucu yürüme ile gelen ve gastroknemius kısalığı olarak

Tablo 2. SP'de alt ekstremite sorunlarında tedavi seçenekleri

\begin{tabular}{|c|c|c|}
\hline Tedavi & Amaç & Yöntem \\
\hline \multirow[t]{3}{*}{ Ortez tedavisi } & \multirow{2}{*}{$\begin{array}{l}\text { Eklemlerin stabilitesini veya mobilitesini } \\
\text { desteklemek. }\end{array}$} & AFO (ayak bileği-ayak ortezi) \\
\hline & & Diz immobilizer (sabitleyicisi) \\
\hline & Kas ve tendon fonksiyonlarına yardımcı olmak. & DAFO (dinamik ayak bileği-ayak ortezi) \\
\hline \multirow[t]{2}{*}{ Spastisite tedavisi } & \multirow{2}{*}{$\begin{array}{l}\text { Bölgesel ya da genel olarak kas tonusunu ve } \\
\text { kasılmalarını düzenlemek. }\end{array}$} & Botilinum toksin nörolizi \\
\hline & & Oral ilaçlar (santral etkili kas gevşeticiler) \\
\hline Rehabilitasyon & $\begin{array}{l}\text { Çok yönlü yaklaşımlar ile yeniden-eğitimi } \\
\text { sağlamak. }\end{array}$ & $\begin{array}{l}\text { Fizyoterapi, ev programları, aktiviteler, hipoterapi, hidroterapi, nöro- } \\
\text { gelişimsel terapi, ergoterapi }\end{array}$ \\
\hline \multirow[t]{6}{*}{ Ortopedik cerrahi } & \multirow{2}{*}{$\begin{array}{l}\text { Bölgesel olarak hedef eklem fonksiyonunu } \\
\text { düzeltmek ya da artırmak. }\end{array}$} & Tenotomiler (örn., adduktor tenotomi) \\
\hline & & Kas-tendon uzatmaları (örn., gastrokinemius uzatması) \\
\hline & Eklem stabilitesini sağlamak. & Tendon transferleri (örn., split tibialis posterior tendon transferi) \\
\hline & \multirow{3}{*}{$\begin{array}{l}\text { Bölgesel olarak hedef kaslarda fonksiyonu } \\
\text { düzeltmek ya da artırmak. }\end{array}$} & Osteotomiler (örn., proksimal femur derotasyon varizasyon ve kısaltma) \\
\hline & & Stabilizasyonlar (örn., talonaviküler artrodez) \\
\hline & & Büyüme modülasyonu (örn., femur distal anterior epifizyodez) \\
\hline
\end{tabular}




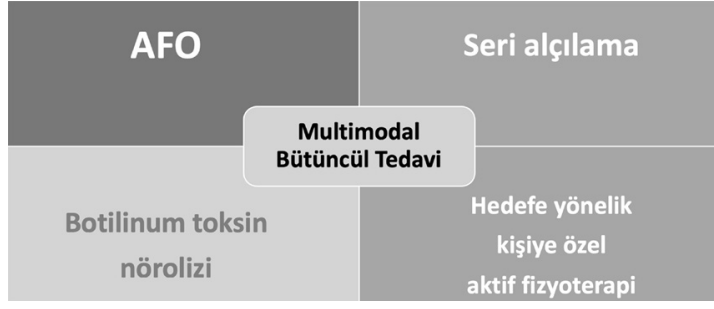

Şekil 3. Parmak ucu yürümede multimodal ve bütüncül yaklaşım (AFO, ayak bileği-ayak ortezi).

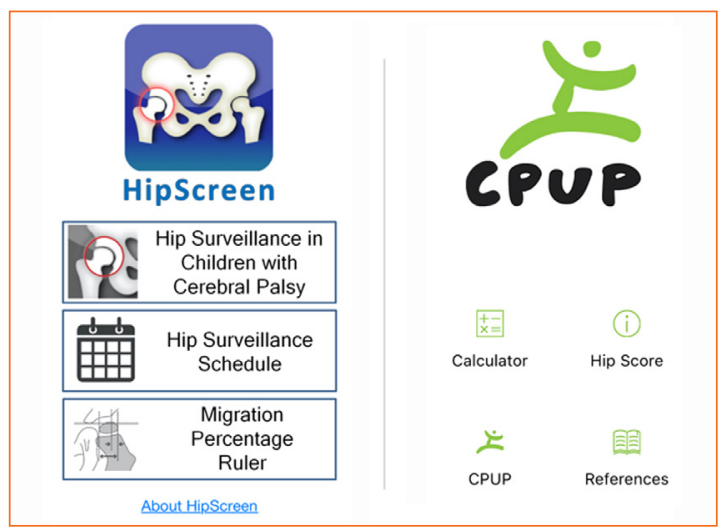

Şekil 5. SP'li hasta takibinde kullanılan akıllı telefon uygulamaları.

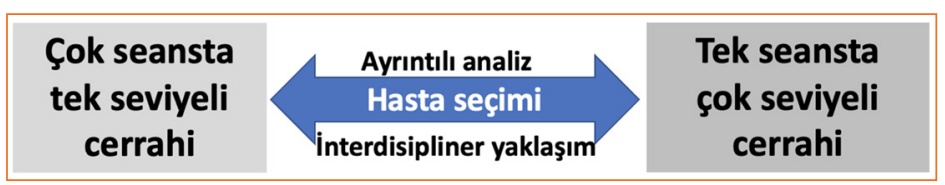

Şekil 4. SP'de ayrı veya aynı seans cerrahi yaklaşımı.

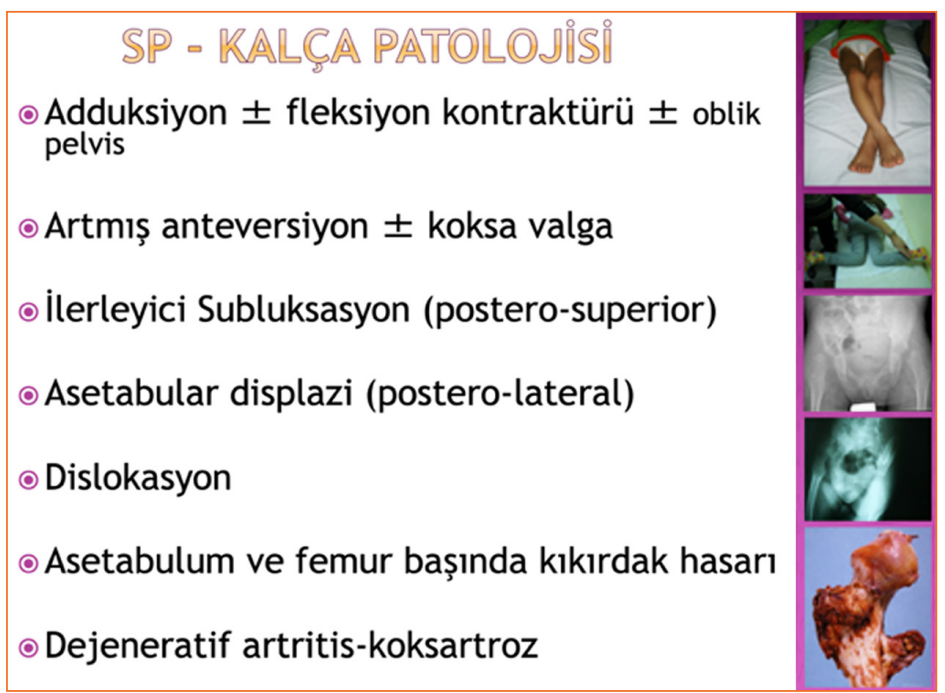

Şekil 6. SP'deki kalça hastalığının fizyopatolojik özeti. değerlendirilen SP'li diplejik hareketli çocukta multimodal bir tedavi planı oluşturarak kas-iskelet deformitesi gelişimi önlenebilir (Şekil 3).

\section{Aynı Seansta Çok Seviyeli Cerrahi (SEMLS)}

Son yıllarda öne çıkan sosyoekonomik avantajları nedeniyle SEMLS (Single Event Multilevel Surgery) ülkemizde yaygın hale gelmiştir. Mercer Rang'in tanımladığı ve 'yaş günü cerrahisi sendromu' diye özetlenen, etkilenen kas ve/veya kemiklerin ardışık ve tekrarlayan cerrahilerinin getirdiği sorunlardan kaçınmak olan bu yaklaşım uzun yıllardır kullanılmaktadır.

Seçilmiş olgularda ve titiz bir değerlendirme süreci sonrasında SEMLS yaklaşımı başarılıdır ve hasta/aile memnuniyeti yüksektir (Şekil 4). ${ }^{[6,7,22-24]}$ Ancak uygun olmayan cerrahi endikasyonlar ve ameliyat sonrası rehabilitasyonun yetersiz olması sonucu istenilen hedefe ulaşılamayabilir. Kas-iskelet sistemi cerrahilerinin geri dönüşünün olmadığı unutulmamalıdır. ${ }^{[35]}$

\section{Riskli Kalça Takibinde Akıllı Telefon Uygulamaları}

SP'li hastalarda kalça sorunlarının takip ve tedavisinde en önemli görev ortopedi uzmanına aittir. Son yıllarda geliştirilen akıllı telefon uygulamaları kullanılarak günlük yoğun pratikte SP'li hastalarda kalça değerlendirmesi ve risk hesaplaması daha kolay bir şekilde yapılabilir (Şekil 5).

\section{Kalça Çıkığı Takip Kılavuzları ve Koruyucu Cerrahi}

Kalça, vücudun en büyük eklemlerinden biridir. SP'li hastalarda kalça çevresindeki adduktor ve fleksör kaslardaki hakimiyeti arttığında (Kaba Motor Fonksiyon Sınıflama Sistemi, KMFSS derecesine göre) \%60'lara varan oranlarda ilerleyici (progresif) kalça subluksayonu (kısmi çıkığı) ve dislokasyonu (tam çıkığı) görülebilmektedir (Şekil 6). Eğer zamanında koruyucu/önleyici tedavi uygulanmaz ise oluşabilecek patolojiler hastaların günlük yaşam kalitesini ciddi olarak bozabilir (Şekil 7).

SP kalça hastalığındaki değişik patofizyolojik özellikler, gelişimsel kalça displazisinde (GKD) uygulanan klasik yaklaşımdan farklı tedavi algoritmaları kullanmayı gerektirir. Güncel olarak Graham HK ve ark.'nın Avustralya kılavuzları temel alınan ve sık kullanılan hasta takip yoludur. Erken dönemde uygulanan multimodal bütüncül tedavi hastanın KMFSS seviyesine göre farklılıklar göstermesine rağmen kalça eklemini korumada oldukça etkilidir (Şekil 8). Başarı oranının daha düşük olduğu KMFSS IV-V hastalarda da aynı yaklaşım işlevsel gerekçelerle rutin olarak uygulanabilir. ${ }^{[11,25-27]}$ 


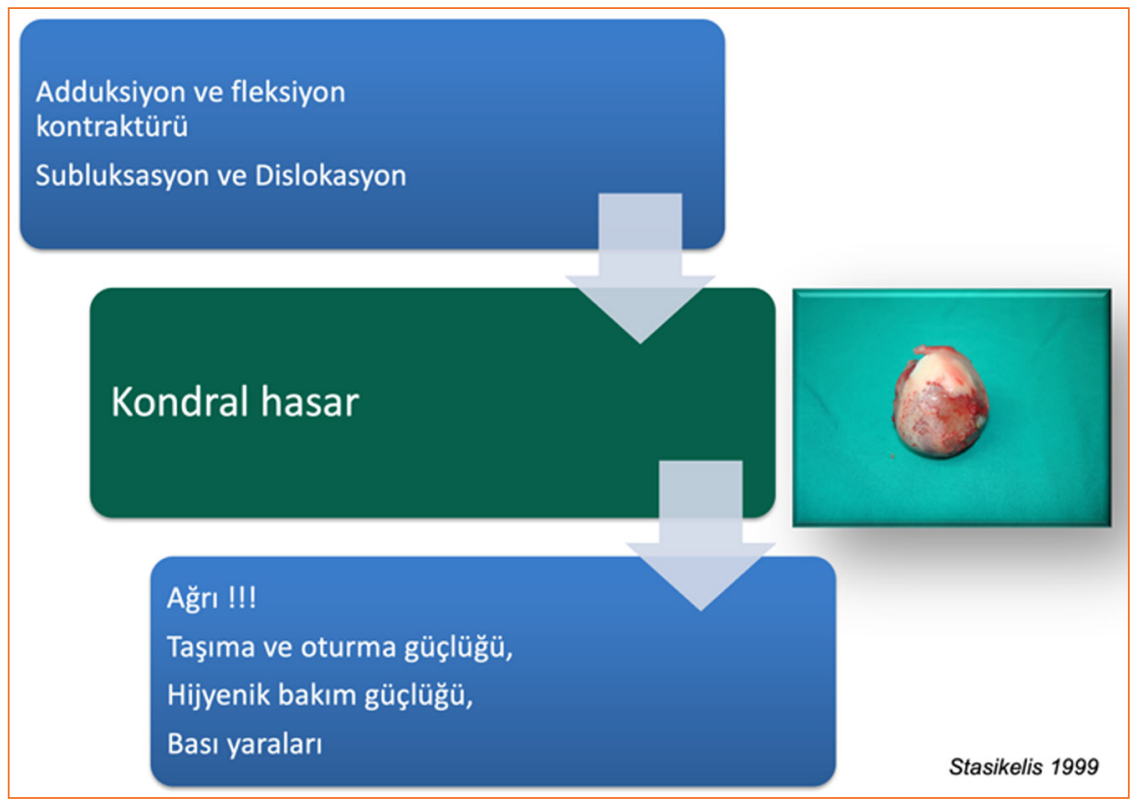

Şekil 7. SP kalça hastalığı erken dönemde tedavi edilmezse morbiditesi artar.

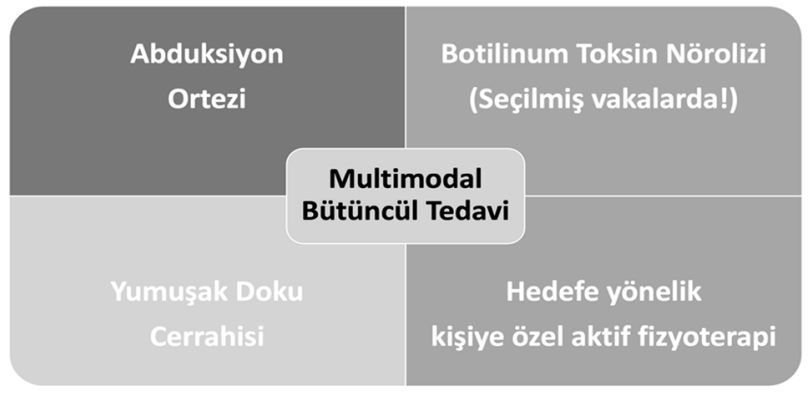

Şekil 8. Erken dönem SP kalça hastalığındaki tedavi yaklaşımı.

\section{Rekonstrüktif Kalça Cerrahisi}

Kalça yarı çıkı̆̆ı (Reimers'in migrasyon indeksinin \%40'ın üzerinde olduğu) ile gelen ve değişik derecelerde asetabular patolojinin eşlik ettiği SP'li kalça hastalarında mümkün olan en ideal kalça anatomisini elde etmek amacıyla aynı seansta yumuşak doku ve kemik ameliyatları ile restorasyonu sağlamak ve en kısa zamanda cerrahiye özel, erken dönemde pasif ve geç dönemde aktif rehabilitasyon programı uygulamak güncel yaklaşımdır (Tablo 3). ${ }^{[3,11,21,22,25-29]}$ Büyük çaba ile karmaşık cerrahi yapıldığında, her zaman SP'li hastaların büyük kazançlar elde edeceği düşünülmemelidir. ${ }^{[11,16,28,29]}$

\section{Pediatrik Kilitli Kalça Plakları (PKP)}

Özellikle hareketliliği kısıtlı ve osteoporotik SP'li hastalardaki kalça hastalığının tedavisindeki rekonstrüktif cerrahide komplikasyonları azaltan ve başarıyı artıran önemli faktörlerden biri, osteotomi sonrası iyi bir tespitin elde edilmesidir. ${ }^{[5,24]} \mathrm{Bu}$ amaçla farklı seçenekler olmakla birlikte, güncel pratikte pediatrik kilitli kalça plakları tercih edilebilir (Şekil 9. a, b; Şekil 10 ve 11).

Tablo 3. SP'li kalça hastalığında rekonstrüktif kalça cerrahisi bileşenleri

\begin{tabular}{ll}
\hline Teknik & Amaç \\
\hline Femoral varus derotasyon osteotomisi (VDO) & $\begin{array}{l}25^{\circ}-30^{\circ} \text { anteversiyon ve } 100^{\circ}-130^{\circ} \text { varizasyon hedeflenerek iyi bir kalça stabilitesi } \\
\text { sağlamak amaçlanır. }\end{array}$ \\
Femoral kısaltma osteotomisi & Kalça migrasyonunu engellemek ve avasküler nekroz olasıllığını azaltmak hedeflenir. \\
Periasetabular pelvik osteotomi & $\begin{array}{l}\text { Dega, Pemberton vb. osteotomiler ile konsantrik redüksiyonun elde edilmesi ve uygun } \\
\text { örtünmenin sağlanması amaçlanır. }\end{array}$ \\
Yumuşak doku cerrahisi & $\begin{array}{l}\text { Adduktor longus tenotomisi, iliopsoas tenotomi ya da apofizden ayrıştırılması ve/veya } \\
\text { medial hamstring tendon ve kaslarının uzatma ya da transferi ile kas çevresindeki yumuşak } \\
\text { dokuların serbestleştirilerek istenmeyen bozucu etki eden kuvvetlerin dengelenmesi } \\
\text { amaçlanır. }\end{array}$
\end{tabular}




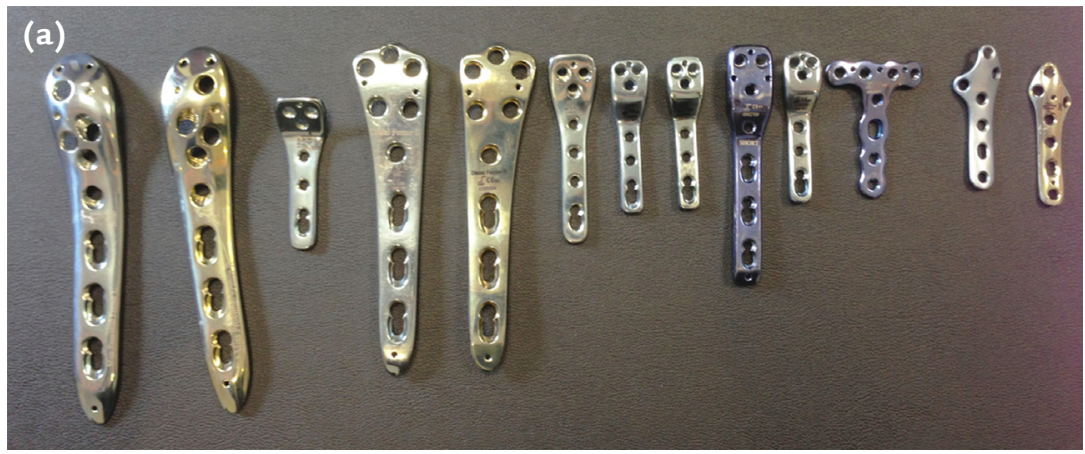

Şekil 9. a, b. Osteotomi sonrası farklı plaklar (a) veya anatomik pediatrik kilitli plakları içeren POS (Pediatrik Osteotomi Seti) (b) kullanılabilir.
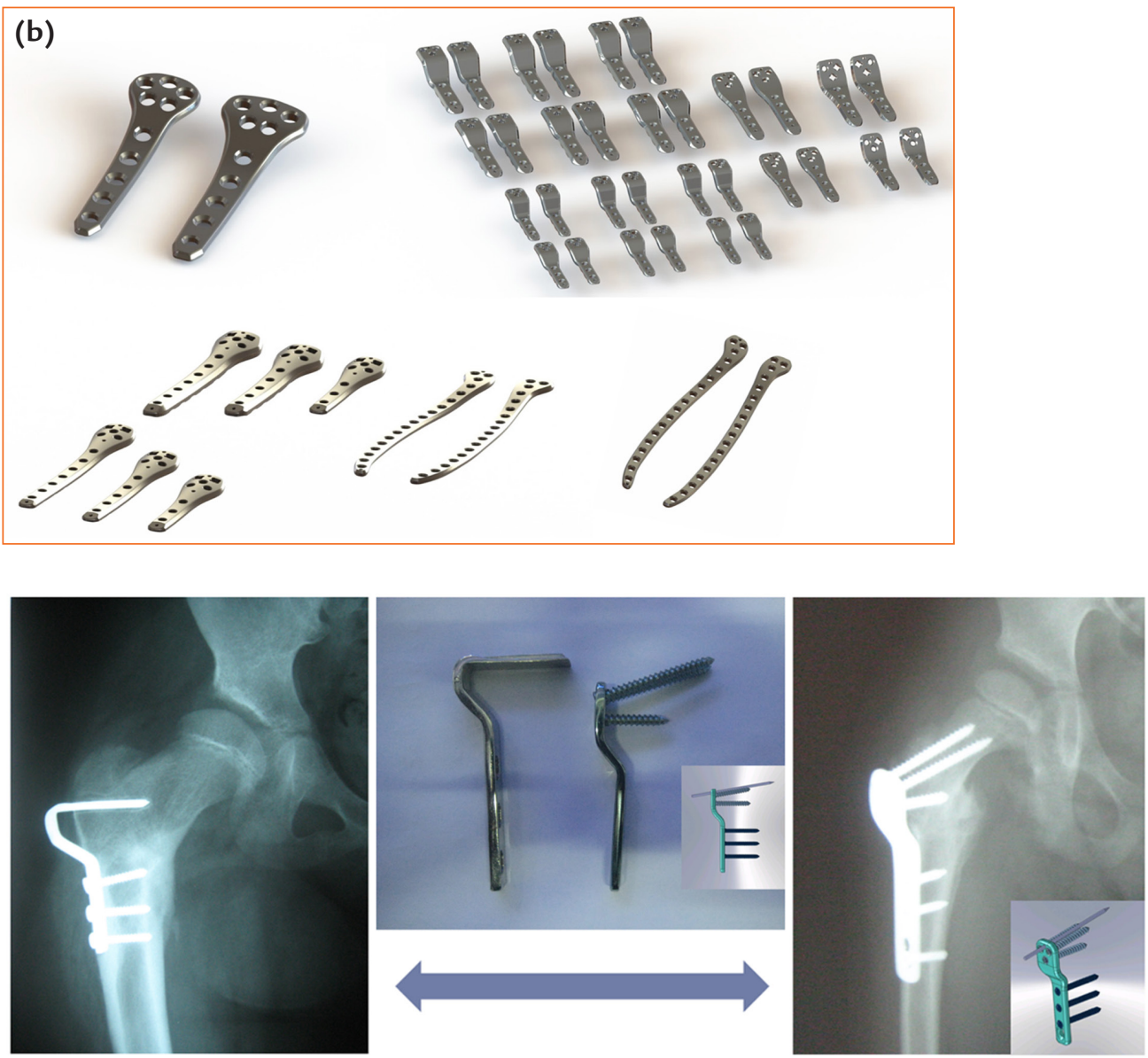

Şekil 10. Pediatrik kalça plakları: Harris Müller vb. PKP.

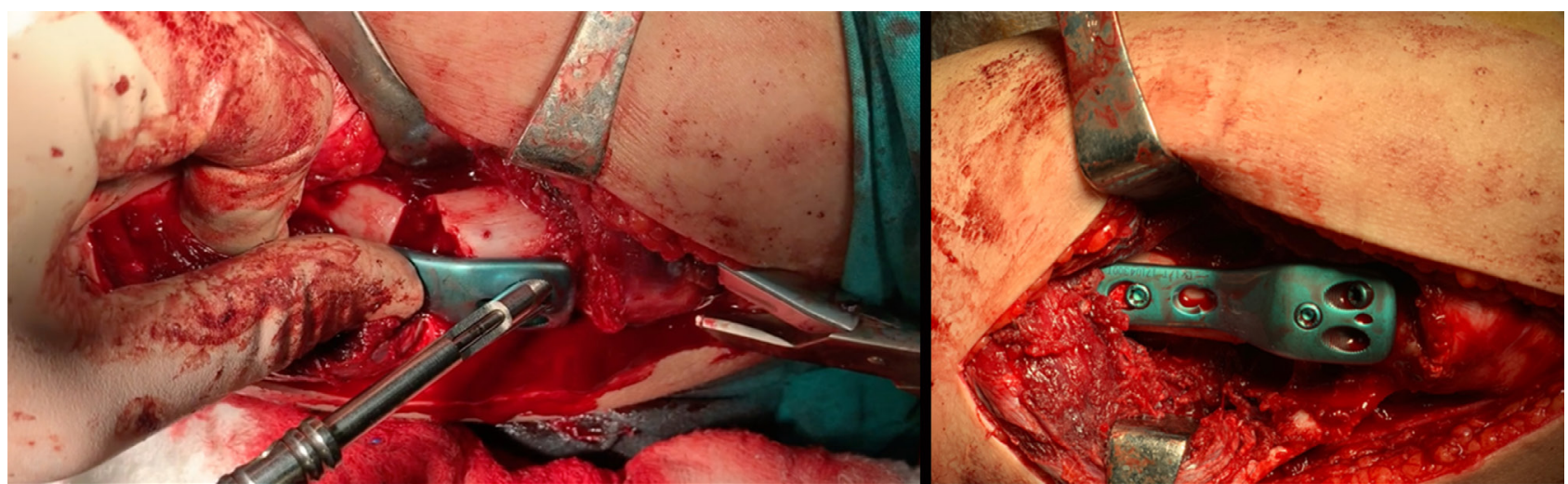

Şekil 11. Derotasyon, varizasyon osteotomisi ve pediatrik kilitli plak (PKP) uygulaması ameliyat içi görünüm. 

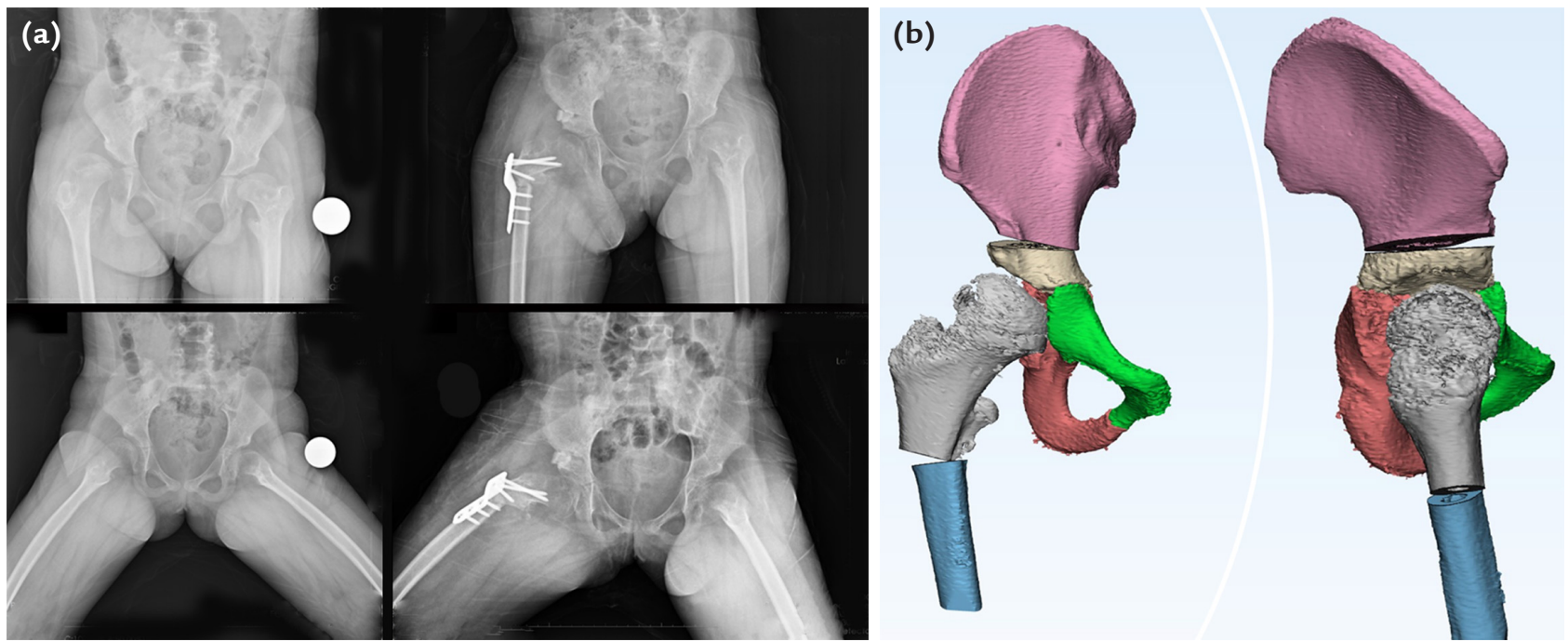

Şekil 12. a, b. SP kalça hastalığında rekonstrüktif cerrahi: Ameliyat öncesi ve sonrası radyografiler (a), ameliyat öncesi 3D planlama ve simülasyon (b).

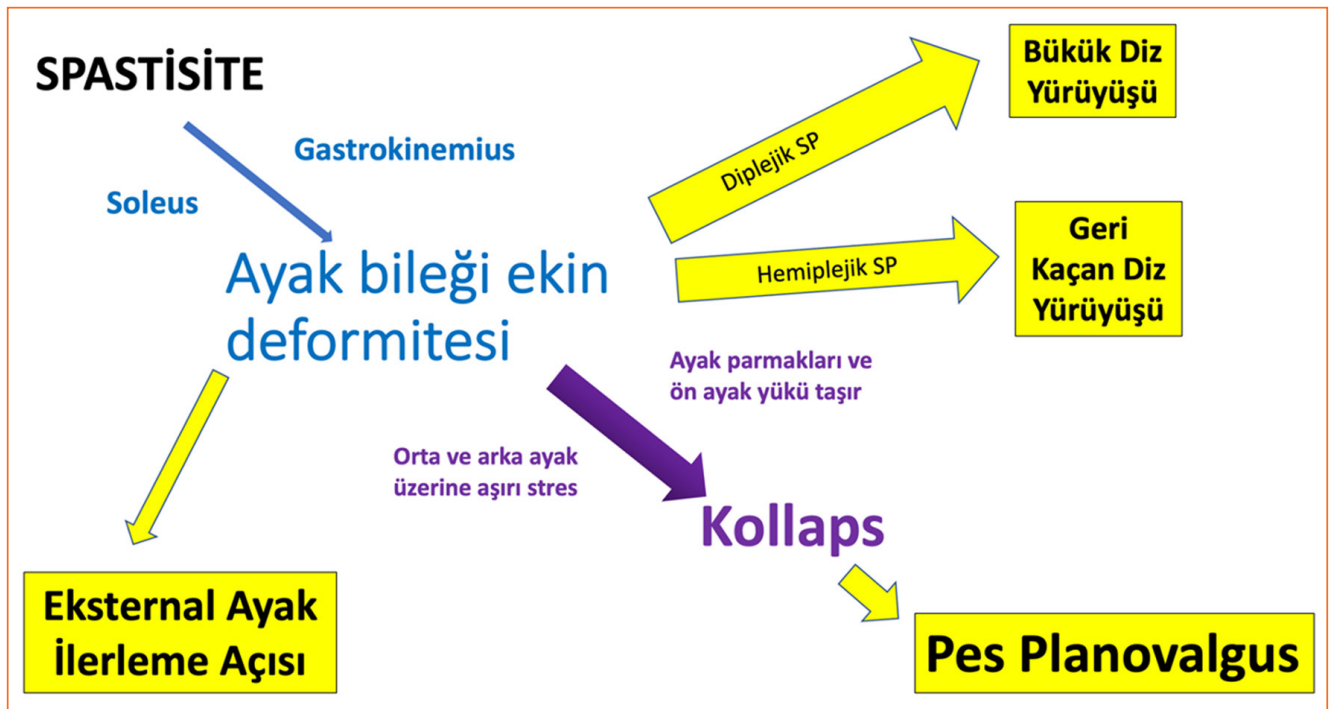

Şekil 13. Spastisite sonucu gelişen kompleks pes planovalgus. ${ }^{[18]}$

Günümüzde birçok farklı PKP ve uygulama setleri bulunmaktadır. Ameliyat içinde cerraha esnek davranabilmesini ve çözüm üretebilmesini kolaylaştıran PKP ve 'Pediatrik Osteotomi Seti' (POS) ile ameliyat içi komplikasyon riski azaltılabilir (Faydalı Model, Tescil Numarası: TR 2015 06846). ${ }^{99,10,12,16,35]}$

\section{D (Üç boyutlu) Osteotomi Planlama ve Simülasyonu}

Son yıllarda 3D modelleme özellikli ameliyatların planlamasında kullanılmaktadır. SP'li kalça hastalığında özellikle rekonstrüksiyon düşünülen olgularda 3D planlama ile simülasyon ameliyat öncesi karar açısından yararlı olmaktadır (Şekil 12. a, b). Yeni teknoloji ve yazılımların geliştirilmesi ile bu yöntem şu an kullanılandan belki çok daha farklı şekliyle ama daha yaygın olarak kullanılacaktır. ${ }^{[17]}$

\section{Talonaviküler Artrodez}

Ayak arklarımız, kemersel mimari yapıları ile, vücudumuzun harika yapılarıdır. Plantigrad basan bir ayağa sahip olmak yürüyüş ve ayakkabı kullanımı için temel şarttır. SP'de görülen ayak deformiteleri içerisinde kompleks etyopatogenezi ile pes planovalgus ağrı, kallus ve ülser oluşumuna, ortez kullanımında zorluklara ve yürüme bozukluklarına neden olmaktadır (Şekil 13). Özellikle diplejik ve kuadriplejik çocuklarda çok sık görülmektedir. ${ }^{[18]}$ 

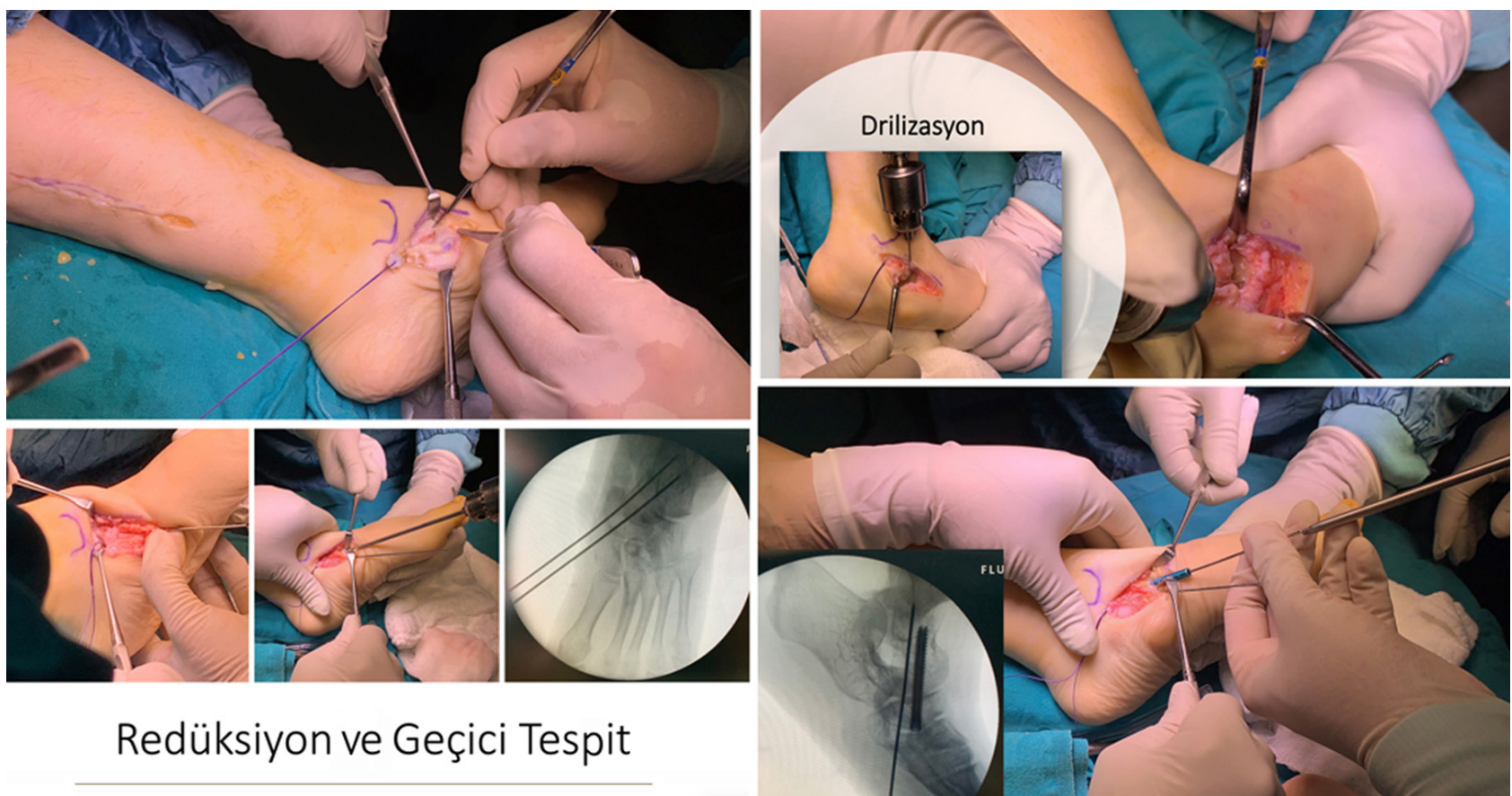

\section{Redüksiyon ve Geçici Tespit}

Şekil 14. Pes planovalgus tedavisinde 'Gastroknemius uzatma + Talonaviküler artrodez + Posterior tibial tendon kısaltma + Kapsülorafi': Ameliyat içi görüntüler.

Pes planovalgus cerrahi tedavi seçenekleri; 1) GreenGrice ekstraartiküler (eklem dışı) artrodez, 2) kalkaneus lateral kolon uzatma, 3) kalkaneal kaydırma osteotomisi ve 4) triple artrodezdir. Ancak ayak deformitesini instabilitenin en fazla olduğu ve CORA noktasına yakın yerden düzeltme sağlayan 'talonaviküler artrodez, posterior tibial tendon (PTT) kısaltma ve kapsül tamiri' yazarın tercih ettiği yöntemdir (Şekil 14 ve 15). Talonaviküler eklemin artrodezi ile stabil bir longitudinal (uzunlamasına) ark ve uzun bir kaldıraç kolu elde edilir. Bu uzun kaldıraç kolu hastada enerji kullanımını azaltarak yürüme mesafesi ve potansiyelinde ilerleme sağlar. Ayrıca ağrı, kallus ve ülser gelişim riski azalır, hasta daha rahat ortez kullanabilir. Yöntemin başlıca avantajları arasında; daha az invaziv olması, düşük komplikasyon oranı, ameliyat sonrası daha az ağrı ve hızlı iyileşme olması, fonksiyonel ve kozmetik olarak hasta memnuniyetinin yüksek olması, yürüme mesafe ve becerisini olumlu etkilemesi ve ekonomik olması sayılabilir.

\section{Diz Fleksiyon Kontraktürleri}

SP'deki deformiteler bir legonun parçası gibi düşünülmelidir. Diz fleksiyon kontraktürleri (DFK) yürüme kinematiğini (aşırı enerji gereksinimi) anormal bir şekilde değiştirerek, eklemlere binen yükleri etkiler ve hastanın konforunu ve hareketliliğini bozar. Tedavi gecikirse eklem hareket açıklığı kaybı, bükük diz yürüyüşü, diz

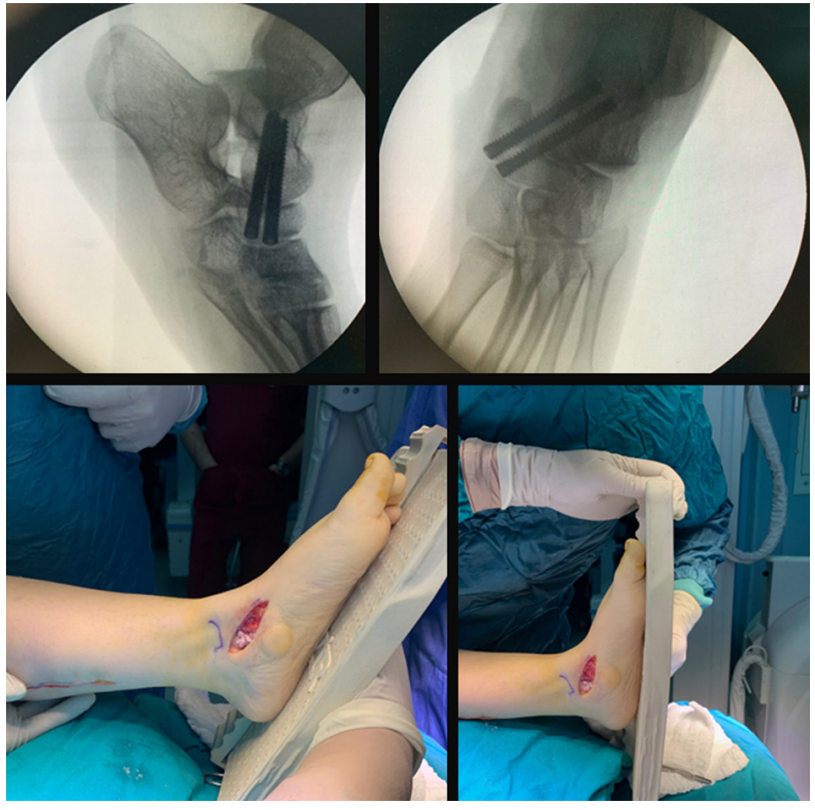

Şekil 15. Ameliyat sonrası radyolojik ve klinik görünüm.

önü ağrısı ve günlük aktivitelerinde ve yaşam kalitesinde kötüleşme başlar. Bölgesel olarak kondromalazi patella, 'fasulye' şeklinde patella deformitesi, patella alt uç avülsiyonları ve stres kırıklarına yol açabilir. Genel olarak ise kalça ve ayak bilek eklemlerini de etkilemeye başlar. Bel/kalça sorunlarını da tetikler (Şekil 16). 


\section{Kalça fleksiyon kontraktürü}

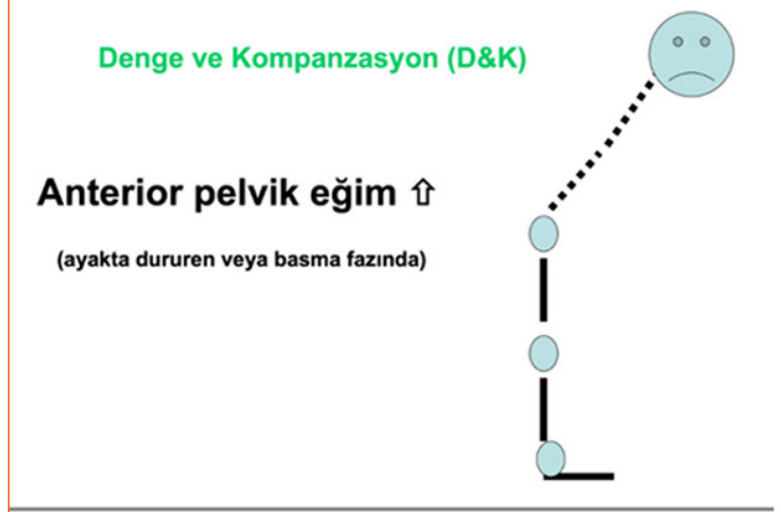

\section{Kalça fleksiyon kontraktürü}

\section{Lomber lordozda artış}<smiles></smiles>

Gövdenin üstü geriye hareket eder

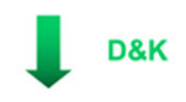

Diz Fleksiyonu

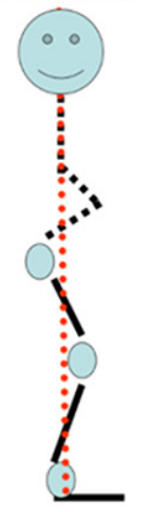

Şekil 16. DFK bir neden ya da sonuç olabilir.

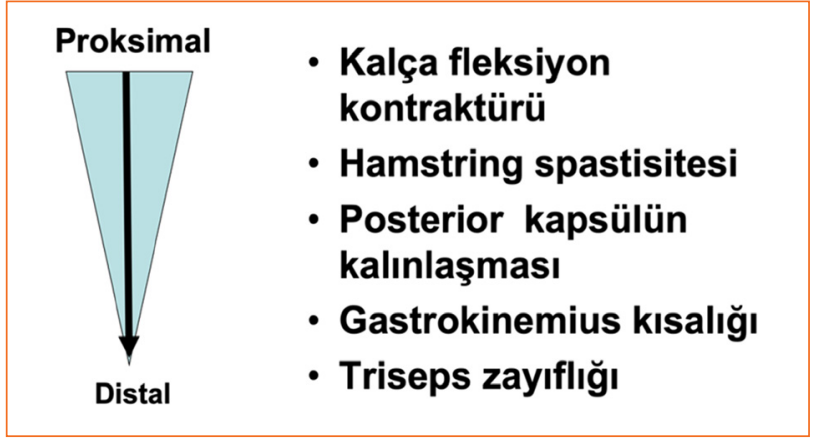

Şekil 17. Diz fleksiyon kontraktüründe patoloji piramidi.

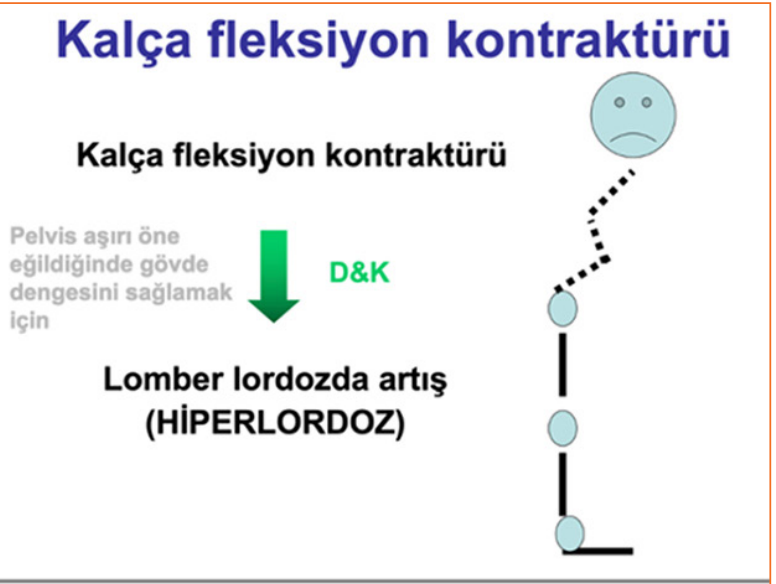

\section{Kalça fleksiyon kontraktürü}

Lomber lordozda artış

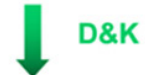

Gövdenin üstü geriye hareket eder

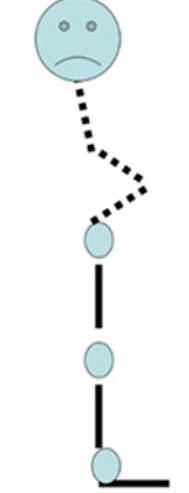

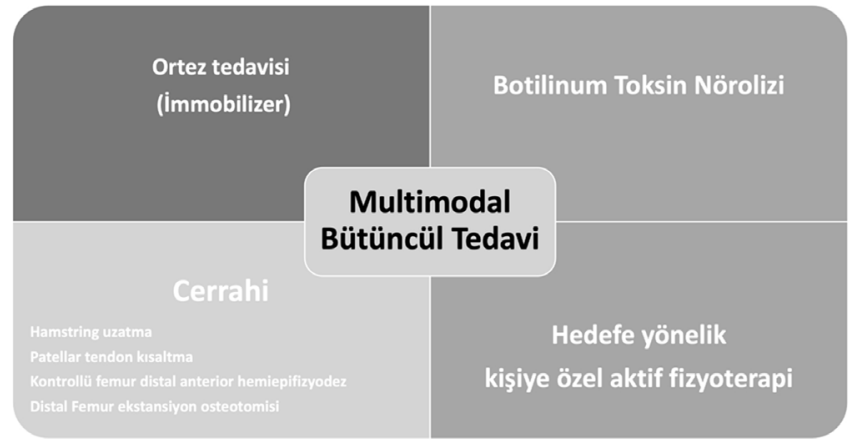

Şekil 18. Diz fleksiyon kontraktürü tedavi algoritması.
DFK'nin izole bir sorundan ya da çok farklı patolojilerin piramit şeklinde eklenmesiyle de oluşabilir (Şekil 17). Tek bir neden olmadığı için birçok farklı tedavi seçenekleri de bütüncül bir yaklaşım içinde değerlendirilmelidir (Şekil 18). ${ }^{6,15,21,30-32]}$

\section{Kontrollü Femur Distal Anterior Hemiepifizyodez}

Onbeş derecenin üzerindeki deformitelerde konservatif tedavi etkili olamayacağından cerrahi seçenekler düşünülmelidir. Diz ekstansiyon osteotomisi gibi büyük cerrahi (komplikasyon oranı yüksek ve pahalı) uygulansa da DFK tekrarlayabilir (Şekil 19).

Yazar 2009 yılından itibaren seçilmiş olgularda minimal invaziv olması, düşük komplikasyon oranı, erken harekete izin verebilmesi ve ekonomik olması gibi avantajlarından dolayı '8 plak' ile DFK tedavisine başlamıştır (Şekil 20). Yazarın 2016 yılında yürüttüügü tez çalışmasının sonuçlarında tekniğin etkinliği ve hasta memnuniyetinin yüksek olduğu saptanmıştır. ${ }^{[13-15,34]}$ 


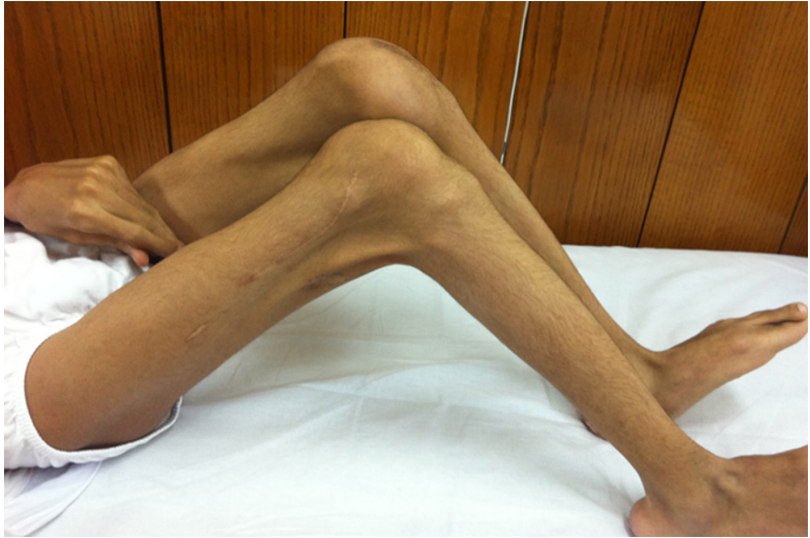

Şekil 19. DFK nedeniyle femur distal ekstansiyon osteotomisi uygulanan ancak hala deformitesi devam eden bir hastanın klinik görünümü.

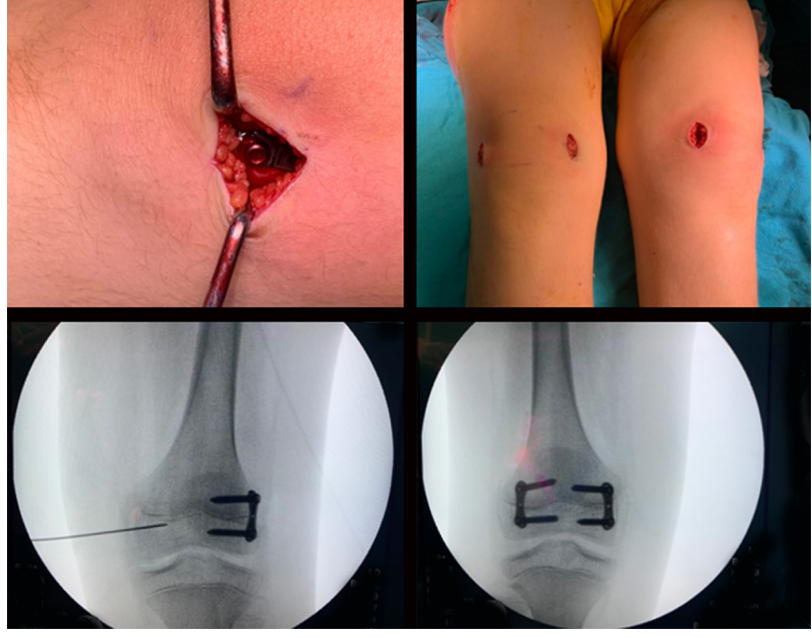

Şekil 20. SP'de DFK tedavisinde uygulanan kontrollü femur distal anterior hemiepizyodez tekniğinin ameliyat içi klinik ve skopi görüntüleri.

Güncel pratiğimizde alt ekstremite sorunlarının çözümüne yönelik her hastanın gereksinimine uygun 'a la carte' birçok ortopedik cerrahi yöntemi seçebilmekteyiz (Tablo 4). Yeni çalışmaların takip sonuçlarının yayımlanması ileriye dönük bir çok farklı tedavi yaklaşımı için umut vericidir (Tablo 5).

Tablo 4. SP'de güncel olarak uyguladığımız alt ekstremitedeki ortopedik cerrahi yöntemler

\begin{tabular}{|c|c|c|c|}
\hline Ameliyat & Zamanlama & Endikasyon & Teknik \\
\hline $\begin{array}{l}\text { Adduktor longus } \\
\text { tenotomisi }\end{array}$ & $\begin{array}{l}\text { İdeal aday sekiz yaşından } \\
\text { (tercihen dört yaş) küçük } \\
\text { hareketli çocuk. }\end{array}$ & $\begin{array}{l}\text { Kalça adduksiyon kontraktüründe } \\
\text { abduksiyonu artırmak, makaslama } \\
\text { yürüyüşünü iyilesstirmek, riskli kalça (migrasyon } \\
\text { indeksi >\%20), simetri sağlama, ağrı tedavisi. }\end{array}$ & $\begin{array}{l}\text { Supin (Sırtüstü) pozisyonda, kasıkta } \\
\text { adduktor longus üzerinde } 3 \mathrm{~cm} \text { 'lik insizyon ile } \\
\text { origosunun yaklaşı } 1 \mathrm{~cm} \text { distalinden adduktor } \\
\text { longusa ulaşılır. Koter ile gevşetme yapılır. }\end{array}$ \\
\hline $\begin{array}{l}\text { Intramusküler psoas } \\
\text { uzatma }\end{array}$ & $\begin{array}{l}\text { Hareketli çocuklarda } \\
\text { (kalçada aşırı fleksiyon } \\
\text { güçsüzlügüünü engellemek } \\
\text { için) diğer tenotomiler } \\
\text { ile (SEMLS) eş zamanlı } \\
\text { yapılabilir. }\end{array}$ & $\begin{array}{l}\text { Ilerleyen kalça fleksiyon deformitesi } \\
\text { (Thomas testi }>15^{\circ} \text { ), yürürken kalçanın } \\
\text { iç rotasyona dönmesi ve aşırı anterior } \\
\text { pelvik eğim ile artmış lomber lordoz } \\
\text { varlığı, kalça ekstansiyon kısıtılığı, diz } \\
\text { fleksiyon kontraktürü. }\end{array}$ & $\begin{array}{l}5 \mathrm{~cm} \text { bikini insizyonu ile sartorius ve tensor } \\
\text { fascia lata arasındaki internervöz plandan } \\
\text { iliopsoasın posteriomedial tarafına ulaşılır } \\
\text { ve tendinöz kısım gevşetilirken musküler } \\
\text { kısmın bütünlüğü korunur. }\end{array}$ \\
\hline $\begin{array}{l}\text { Trokanter minörden } \\
\text { iliopsoas tenotomisi }\end{array}$ & $\begin{array}{l}\text { Diğer tenotomiler ile } \\
\text { (SEMLS) eş zamanlı } \\
\text { yapılabilir. }\end{array}$ & $\begin{array}{l}\text { Ilerleyen kalça fleksiyon deformitesi } \\
\text { (Thomas testi > } 15^{\circ} \text { ), yürürken kalçanın } \\
\text { iç rotasyona dönmesi ve aşırı anterior } \\
\text { pelvik eğim ile artmış lomber lordoz } \\
\text { varlığı, kalça ekstansiyon kısıtıılığı, diz } \\
\text { fleksiyon kontraktürü. }\end{array}$ & $\begin{array}{l}\text { İnguinal ligamentin } 1-3 \mathrm{~cm} \text { distalinden } \\
\text { yapılan bir transvers insizyonla adduktor } \\
\text { brevise ulassılır ve } 45^{\circ} \text { abduksiyon } \\
\text { sağlanana kadar tenotomize edilir. } \\
\text { Adduktor tenotomi ile birlikte yapacaksak } \\
\text { aynı insizyondan trokanter minöre } \\
\text { ulaşılarak yapışma yerinden ayrılır. }\end{array}$ \\
\hline Dega pelvik osteotomi & $\begin{array}{l}\text { 'Y' (Triradiat) kıkırdak } \\
\text { kapanmadan önce. }\end{array}$ & $\begin{array}{l}\text { VDRO'ya ek olarak kombine yapılma } \\
\text { ile ilgili kesin endikasyon yoktur. } \\
\text { Ancak asetabular displazi ve kalça yarı } \\
\text { çıkığı ya da çıkığı varlığında yapılabilir } \\
\text { (migrasyon indeksi >\%50, asetabular } \\
\text { indeks }>25^{\circ}-35^{\circ} \text {, Tip II kaş bulgusu, } \\
\text { ameliyat içi kontrolde instabilite). }\end{array}$ & $\begin{array}{l}\text { Illium iç korteksinin anteromedialinden } \\
\text { inkomplet osteotomi ile alınan bir kemik } \\
\text { blok; triradiat kıkırdağın iliopubik ve } \\
\text { ilioiskial kollarının hemen üzerinden } \\
\text { yapılan ve oblik olarak inferomediale } \\
\text { uzanan osteotomi hattına impakte edilir } \\
\text { (sıkıştıııır). }\end{array}$ \\
\hline
\end{tabular}


Tablo 4. SP'de güncel olarak uyguladığımız alt ekstremitedeki ortopedik cerrahi yöntemler (devam)

\begin{tabular}{|c|c|c|}
\hline Ameliyat & Zamanlama & Endikasyon \\
\hline $\begin{array}{l}\text { Proksimal femur varus } \\
\text { derotasyon osteotomisi } \\
\text { (VDRO) }\end{array}$ & $\begin{array}{l}\text { İki yaştan itibaren } \\
\text { yapılabilir, ancak } \\
\text { ortalama yaş yedidir. }\end{array}$ & $\begin{array}{l}\text { Kalça yarı çıkığı veya çıkığının eşlik ettiği } \\
\text { proksimal femurun ileri derecede valgus } \\
\text { deformitesi ve anteversiyonu. (Migrasyon } \\
\text { indeksi >\%50) }\end{array}$ \\
\hline
\end{tabular}
Teknik

Proksimal femur derotasyon osteotomisi

Ortalama yaş: 9-11.

İnternal (iç) rotasyonda yürümeyi düzeltmek amaçlanır.

Çocukluk ve erişkin yaşta da yapılabilir.

Proksimal femur rezeksiyon artroplastisi

Femur başı rezeksiyonu ve valgus osteotomisi

Total kalça artroplastisi Erișkin.

Medial hamstring uzatma

Yürüme çağındaki çocuklar.

Lateral hamstring

uzatma

Distal rektus femoris intramusküler uzatma

Distal rektus femoris transferi (DRFT)

Distal femur ekstansiyon osteotomisi (DFEO) + Patellar tendon kısaltma veya aşağıya indirme (PTA)
Yürüme çağındaki çocuklar.

Ortalama 4-14 yaşları arasında.

Ortalama 4-14 yaşları arasında.

Net değil. Ancak büyümesi tamamlanmış hastalarda tekrarlama riski düşüktür. Sekiz ila yirmi bir yaş için yayınlar vardır.
Ağrılı kronik kalça çıkığı olan yürüyemeyen çocukların ağrısız oturabilmesi ve perineal bakımlarının yapılabilmesi amaçlanır (kurtarıcı ameliyat).

Ağrılı kronik kalça çıkı̆̆ı, oturmada güçlük, hijyende/perine bakımında zorluk, dekubit ülserleri (kurtarıcı ameliyat).

ideal aday mental fonksiyonları yeterli, kendi başına hareketliliğini sağlayabilen, hafif yumuşak doku kontraktürleri olan ağrılı dejeneratif kalça hastalığı bulunan SP'li hastalar.

$70^{\circ}$ ' den az düz bacak kaldırma, belirgin kemik deformite yokluğunda popliteal açının $135^{\circ}$ 'den az olması durumunda.

Hareketlilik potansiyeli olmayan ileri derecede diz fleksiyon kontraktürü olan kuadriplejik çocuklar.

Tutuk diz ve bükük diz yürüyüşü olup KMFSS I-II ve Duncan-Ely testi pozitif olan hastalar.

Tutuk diz ve bükük diz yürüyüşü olup KMFSS I-II ve Duncan-Ely testi pozitif olan hastalar.

Bükük diz yürüyüşü.

Internal rotasyonda yürümeyi düzeltmek amaclanır. Özellikle distalde ek işlemler uygulanacağında yeğlenir.
Cerrahın tercihine bağlı olarak sırtüstü ya da yüzükoyun pozisyonda femur proksimalinden yapılan longitudinal insizyonla cilt cilt altı ve fasya lata geçilir, vastus lateralis kaldırılıp pediatrik kilitli kalça plağı ya da Harris Müller kalça plağı skopi kontrolü altında ameliyat öncesi planlamaya uygun olarak yerleştirilir.

Cerrahın tercihine bağlı olarak sırtüstü ya da yüzükoyun pozisyonda femur proksimalinden yapılan longitudinal insizyonla cilt cilt altı ve fasya lata geçilir, vastus lateralis kaldırılıp derotasyon osteotomisi yapılır ve pediatrik kilitli kalça plağı veya Harris Müller kalça plağı ile tespit uygulanır.

Sırtüstü pozisyonda trokanter majör üzerinden trokanter minöre kadar $10 \mathrm{~cm}$ 'lik insizyon yapılır. Vastus lateralis, gluteus medius ve minimus, kısa eksternal (dış) rotatorlar, psoas tendonları serbestleştirilir. Trokanter minörün $3 \mathrm{~cm}$ altından proksimal femur rezeksiyonu yapılır (McCarthy, 1988). Asetabular kavite kapsü kenarlarının üst üste dikilmesiyle kapatılır. Ameliyat sonrası cilt ya da iskelet traksiyonu veya pelvipedal alçı uygulanır.

McHale'in tanımladığı femur boyun kesisi ile baş rezeksiyonundan sonra valgus subtrokanterik osteotomi yapılır. PKP ile tespit yapılır. Trokanter minör asetabulum içine yönlendirilir. Ligamentum teres psoasa dikilir.

Asetabular komponentin inklinasyon ve anteversiyonun artırılması ve femurda çimento kullanılması ile stabilite artırılır.

Popliteal katlantıdan 7-10 cm proksimale uzanan medial kesi ile semitendinosus ve semimembranosus'a ulaşılarak Z-plasti uygulanır.

Popliteal cilt katlantısından 7-10 cm proksimale uzanan lateral kesi ile biseps femorise ulaşılarak Z-plasti uygulanır.

Uyluk anterior orta hatta patella superior kenarından 4 parmak proksimalinden 4 $\mathrm{cm}$ 'lik insiziyonla rektus femoris tendonuna künt olarak ulașıır, 1,5 cm'lik kısım eksize edilir ve kasın retrakte olması sağlanır.

Patella üstünden anterior orta hattan yapilan insizyon ile rektus tendonu patellanın superiorundan ayrılır, semitendinosus, sartorius ya da iliotibial banta çekme hattına uygun transfer edilir.

Lateral distal femoral insizyonla girilir, vastus lateralis kaldırılır, koronal plan dizilim hesaplamamıza göre kama çıkarılır, $90^{\circ}$ kamalı plak ya da kilitli anatomik plak ile tespit yapılır. PTA için patellar tendon anterior orta hattından yapılan insizyonla tendona ulaşılır. Cocuk hastalarda distalden periostal flep ile erişkin hastalarda ise kemik blok ile kaldırılıp distale ilerletilir. Patella ile tibia arasına koruyucu takviye uygulanır.

Lateral distal femoral insizyonla girilir, vastus lateralis kaldırilır, osteotomi uygulanır, $90^{\circ}$ kamalı plak ya da kilitli anatomik plak ile tespit yapılır. 
Tablo 4. SP'de güncel olarak uyguladığımız alt ekstremitedeki ortopedik cerrahi yöntemler (devam)

\begin{tabular}{lll}
\hline Ameliyat & Zamanlama & Endikasyon \\
\hline $\begin{array}{l}\text { Patellar tendon } \\
\text { kısaltma }\end{array}$ & $\begin{array}{l}\text { Büyümeyi tamamlamış } \\
\text { ya da sınırlı büyüme } \\
\text { potansiyeli kalmış (2 yıl) } \\
\text { çocuklar. }\end{array}$ & $\begin{array}{l}\text { Bükük diz yürüyüşü } \\
\text { (diz fleksiyonu } 10^{\circ}-30^{\circ} \text { arasında). }\end{array}$ \\
Gastrokinemius uzatma & $\begin{array}{l}\text { Belirtilmemiş (üç yaş altı } \\
\text { çocuklarda tekrarlama } \\
\text { riski yüksek, altı yaş üstü } \\
\text { çocuklarda düşük) }\end{array}$ & $\begin{array}{l}\text { Ileri derece ekin deformitesi/parmak } \\
\text { ucu yürüme (Hareketli bir çocukta } \\
\text { ayak bileğinin nötral pozisyona } \\
\text { getirilememesi, yürüyemeyen bir çocukta } \\
\text { ayakta durma ve hijyen problemlerinin } \\
\text { başlaması) }\end{array}$
\end{tabular}

Perkütan Aşil uzatma Belirtilmemiş (üç yaş altı çocuklarda tekrarlama riski yüksek, altı yaş üstü çocuklarda düşük)
Distal tibia derotasyon osteotomisi

Ortalama altı yaşından itibaren yapılabilir.

Kısmi tibialis anterior tendon transferi

Ortalama beş yaşından itibaren yapılabilir. Yayınlarda 4-16 yaşlar arasında yapıldığı bildirilmiştir. tendon transferi

Ortalama beş yaşından itibaren yapılabilir. Yayınlarda 4-16 yaşlar arasında yapıldığı bildirilmiştir.

Kalkaneus media kaydırma osteotomisi

Ortalama yedi yaş sonrası.

Ortalama yedi yaş sonrası.

Kalkaneus lateral
kaydırma osteotomis

Talonaviküler artrodez

Ortalama yedi yaş sonrası.
Kısmi tibialis posterior

İleri derece ekin deformitesi (Hareketli bir çocukta ayak bileğinin nötral pozisyona getirilememesi, yürüyemeyen bir çocukta ayakta durma ve hijyen problemlerinin başlaması)

Kuwet kolu disfonksiyonuna sebep olan ve yürüyüşü bozan fonksiyonel olarak belirgin internal ya da eksternal tibial torsiyon.

Esnek pes ekinovarus deformitesi.

Esnek pes ekinovarus deformitesi.

Ayak arkası valgusu düzeltilebilecek yumuşaklığı olan ağrılı ve fonksiyonu kısıtlayan ileri planovalgus deformitesi.

Ciddi arka ayak varus deformitesi (ekinokavovarus deformitesi).

Esnek kuwvet kolu disfonksiyonu, ağrı ve cilt bası yaraları ile karakterize pes planovalgus deformitesi.

Ciddi kalkaneovalgus (planovalgus) deformitesi.

Ortalama yedi yas sonrası. Eklem dışı olduğundan daha küçük çocuklarda da uygulanabilir.

Ayak birinci parmak metatarsofalangeal artrodez

Halluks valgus, semptomatik dorsal bunyon.
Teknik

Fizis açık ise yapışma yerinden ayrılan patellar tendon periosteal bir flep altına yerleştirilir. Fizis kapanmış ise tibial tüberkül ile beraber planlanan yere bir adet kompresyon vidası ile tespit edilir. Ferraretto ve Selberin tanımladığı tekniğe göre yapılan kısaltmada ise ek tespitlere gerek duyulmaması avantajdır.

Bacak posteriorunun ortasından yapılan bir insizyon ile muskulotendinöz bileșkeye ulasılarak transvers bir insizyon yapilir ve bu insizyon proksimal ve distalden lateral ve mediale uzatılarak tam bir gevşetme sağlanır.

Yüzükoyun pozisyondaki hastanın Aşil tendonu palpe edilerek üç mini-insizyon ile 'Z' uzatma sağlanır.

Distal tibia diyafizinden osteotomi uygulanır ve en fazla $30^{\circ}$ 'lik bir rotasyon verildikten sonra 4-6 delikli plaklar ile tespit sağlanır.

Medial küneiform üzerinden yapılan bir insizyonla anterior tibial tendona ulaşıır, tendonun lateral kısmı yapışma yerinden ayrılarak küboid üzerinde drille açılan deliğe emilmeyen materyal ile veya sütür ankor ile tespit edilir.

Medial malleolden başlayarak navikulaya uzatılan bir insizyon ile posterior tibial kas ve tendonuna ulaşılır, plantar kısmı navikuladan ayrilarak tendonun ucu tibia ve fibulanın posteriorunda, nörovasküler demetin anteriorunda olacak sekilde geçirilerek peroneus brevise dikilir veya lateral küneiform kemiğe sütür ankor ile tespit edilir.

Mubarek'in tanımladığı şekilde transvers kalkaneal osteotomi sonrası inferior parça tibia-kalkaneus dizilimini sağlayacak şekilde mediale kaydırılır ve kanülü vida ile osteotomi tespit edilir. Medial kuneiform plantar kapalı kama osteotomisi ve medial kapsülorafi de eklenebilir.

Dwyer'ın tanımladığı sekilde osteotomi uygulanır. Ek olarak birinci metatarsal dorsal kama osteotomisi ve tibialis posterior kısmi transferi yapılabilir.

Medialde $3 \mathrm{~cm}$ 'lik insizyonla tibialis posterior tendonu bulunur ve kısaltma yapılır, kapsül eksize edilir ve kapsülorafi uygulanır, eklem ortaya konup kıkırdak dokular uzaklaștırılır. Talonaviküler eklem redükte edilip ön ayak pronasyonu sağlandıktan sonra skopi altında bir ya da iki adet vida ile artrodez uygulanır. Gerekirse ayak bileği valgus deformitesi ve gastrosoleus kısalığı düzeltilir.

Sinus tarsi bulunur, temizlenir. Talus ve kalkaneusa greftin oturacağı yerler açılır ve ölçümden sonra fibuladan, iliak kanattan veya tibiadan alına greft uygun pozisyonda yerleştirilir ve altı hafta diz altı alçı uygulanır.
Birinci parmak dorsalinden yapılan insizyonla dizilim sağlandıktan sonra miniplak ya da vida ile tespit sağlanır. 
Tablo 5. SP alt ekstremite cerrahisi ile ilgili yeni çalışmalar

\begin{tabular}{llll}
\hline Teknik & Makale & Bilgi & Teknik \\
\hline $\begin{array}{l}\text { Endoskopik } \\
\text { gastroknemius uzatma }\end{array}$ & $\begin{array}{l}\text { Endoscopic Transverse } \\
\text { Gastrocsoleus Recession } \\
\text { in Children With Cerebral } \\
\text { Palsy. Kim DW, et al. 2020. }\end{array}$ & $\begin{array}{l}\text { SP'li çocuklarda endoskopik transverse } \\
\text { vulpius gastrosoleus uzatmanın } \\
\text { geleneksel açık cerrahiye kıyasla yürüme } \\
\text { [33] }\end{array}$ & $\begin{array}{l}\text { Karpal tünel gevşetme kılavuzu } \\
\text { kullanılarak 2. anatomik bölgeden } \\
\text { (Gastroknemius medial göbeği }\end{array}$ \\
& & & $\begin{array}{l}\text { ile soleusun terminal kas liflerinin } \\
\text { sonundan) girilerek longitudinal bir } \\
\text { medial kesi ile fasya ayrılır. Sural sinir ve } \\
\text { safen ven korunur. 3,5 mm artroskop ile } \\
\text { girilip, tendon transvers olarak kesilir. }\end{array}$
\end{tabular}

Miniinvaziv selektif perkütan miyofasiyal uzatma

Perkütan hamstring uzatma

Mini-invaziv hamstring uzatma ve seri alçılama

Proksimal femur kontrollü epifizyodez

Subtrokabterik derotasyonel osteotomi ve eksternal tespit
Minimally Invasive SPML Surgery for Children with Cerebral Palsy: Program Development. Wild DL, et a 2020.[24]

Percutaneous Hamstring Lengthening Surgery is as Effective as Open Lengthening in Children With Cerebral Palsy. Nazareth A, et al. 2019. ${ }^{[36]}$

Improved Clinical and Functional Outcomes in Crouch Gait Following Minimally Invasive Hamstring Lengthening and Serial Casting in Children With Cerebral Palsy. Long JT, et al. 2020.[37]

Guided Growth Improves Coxa Valga and Hip Subluxation in Children with Cerebral Palsy. Hsieh HC, et al. 2019. ${ }^{[28]}$

Derotational

Subtrochanteric Osteotomy and External Fixation for the Treatment of Neurogenic Hip Dislocation in Children with Cerebral Palsy: Could This Be a Viable Method of Treatment? Angelis S, et al. 2020. [29]
Çok bölgeli SPLM (selective percutaneous myofascial lengthening) uygulanan SP'li çocuklarda Faz 1 "Prensibin Kanıtlanması"çalışması ile eklem hareket açıklığı ve hareketliliğin arttığını Faz 2 çalışması ile komplikasyon, reoperasyon ve ayak bileği ekinus oranlarını belirlemek.

SP'li çocuklarda açık hamstring uzatma ile perkütan hamstring uzatmanın bükük diz yürüyüşü ve diz fonksiyonları açısından kıyaslanması.

Diz kontraktürü nedeniyle hamstring uzatma uygulanmış SP'li çocuklarda seri alçılama sonrası diz kontraktürü, yürüyüş fazlarında eklem hareket açıklıklarının değerlendirilmesi.

\author{
T,
}

SP'li çocuklarda endoskopik transverse geleneksel açık cerrahiye kıyasla yürüme

Transfiziyel vida ve adduktor tenotomi koksa valga deformitesi ve lateral

kalça yarı çıkığı üzerine etkili midir? Koksa valganın düzelmesinde ve kalça stabilizasyonunda etkili faktörler nelerdir? Bu tekniğin komplikasyonları nelerdir? Bu teknik sonrası tekrar ameliyat oranları nedir?

Serebral palsili kronik kalça çıkığı mevcut hastalara uygulanabilecek yeni bir yöntem olan varus derotasyon subtrokanterik osteotomi ve eksternal osteosentez kombinasyonunun değerlendirilmesi.
Uyluğun 1/3 distali popliteal katlantının birkaç santimetre proksimalinden semitendinozus tenotomisi; semimembranozus, grasilis, biseps femoris uzatması uygulanır. Kalça adduktorlarına tenotomi uyluğun proksimalinden uygulanacaktır. Çocukta makaslama yürüyüşü varsa obturator sinir bloğu önerilir.

Perkütan hamstring uzatmada semitendinozus tenotomisi için 15 numara bistüri kullanılarak popliteal katlantının birkaç santimetre proksimalinden semitendinosus kolaylıkla perkütan olarak grasilis ve semimebranozustan ayrılmıştır. Perkütan ve açık uygulanan her iki uzatmada da grasilis sağlam bırakılmıştır. Adduktor ve gastrokinemius uzatma sadece ayaktan hastalara uygulanmıştır.

Bütün hastalara açık hamstring uzatma ameliyatı uygulanmış, öncesinde hemiepifizyodez uygulanan hastalar çalışmaya dahil edilmemiştir. Uzun bacak alçılar ameliyat sırasında yapılmış. İkişer hafta ara ile 10 mm'lik kama çıkarılarak hamstring uzatma uygulanmışve 4 . haftada alçı çıkarılmıştır.

Floroskopi kontrolü altında bir adet perkütan transfiziyel vida femur boynundan proksimal femoral fizisin inferomedialinden geçecek şekilde yerleştirilmiştir.

Osteotominin uygulanacağı subtrokanterik alana küçük bir insizyonla girilir. Femur başının asetabulum içerisinde rotasyonal kapasitesini artırmayı hedefleyen tek taraflı osteosentez uygulanır. Altı ay sonra ek bir girişim yapılmadan fiksatör çıkarılır. 
Tablo 5. SP alt ekstremite cerrahisi ile ilgili yeni çalışmalar (devam)

\begin{tabular}{ll}
\hline Teknik & Makale \\
\hline Semitendinosis tendonu & Comparison Between \\
distal femur transferi & Semitendinosus Transfer to \\
& Distal Femur and Medial \\
& Hamstrings Surgical \\
& Lengthening for Treatment \\
& of Flexed Knee Gait in \\
& Cerebral Palsy. Morais F, \\
& et al. 2020. ${ }^{[32]}$
\end{tabular}

Bilgi Teknik

Anterior distal femur hemiepifizyodez

İkili kalkaneal osteotomi

\section{Double Calcaneal}

Osteotomy in Treatment of

Flexible Planovalgus Foot

Deformity in Ambulatory

Cerebral Palsy. A Case Series

Study. Aly AS, et al. 2019.[39]

Anterior Distal Femoral
SP'li çocuklarda semitendinosus transferi ve semitendinozus uzatması yapılan hastaların diz fleksiyon kontraktürü ve bükük diz yürüyüşü açısından karşılaştırı Iması. Hemiepiphysiodesis With Without Patellar Knee Flexion Contractures in Children With Cerebral Palsy. Rethlefsen SA, et al. $2020 .{ }^{[38}$
SP'li diz fleksiyon kontraktürü ve bükük diz yürüyüşü olan çocuklarda anterior distal hemiepifizyodez ile distal femoral uzatma osteotomisi ve patellar tendon uzatma ameliyatı uygulanmış hastaların popliteal açı diz eklem hareketleri ve yürüyüşün duruş fazında ekstansiyon derecesi açısından kıyaslanması.
Hareketli SP'li hastalarda aşırı esnek pes planovalgus deformitesinin tedavisi amaçlanmıştır.
Hasta yüzükoyun pozisyonda yatarken Grup A'da grasilise intramusküler tenotomi semitendinozus ve semimembranozusa 'Z tipi' uzatma uygulanır. Grup B'de ise semitendinozus adduktor tüberküle taşınır.
Anterior distal hemiepifizyodez: Perkütan olarak uygulanmış, 4,5 mm'lik 3-4 mm boyutunda kanüllü vida skopi eşliğinde distal femoral fizisin 1/3'ünden gönderilmiş. Ağrıya neden olması ya da iskelet matüritesi sağlandığında çıkarılmıştır.

Patellar tendon kısaltma: Anterior longitudinal insizyonla girilmiş tibial tüberkülün posteriorundan patella drill ile delinmiştir. Fibertape delikten geçirilmiş patella distale çekilmiştir. Fiberwire ile patellar tendon 'figür 8' şeklinde tutturulmuştur.

Gastrosoleus uzatmasından sonra peroneal tendonların altından oblik insizyonla sural sinire dikkat edilerek kalkaneusa ulaşılır. İnce uçlu kesici ile skopi kontrolünde lateralden mediale osteotomi yapılır. Posterior fragman mediale kaydırılarak valgus düzeltilir. Osteotomiye dik kanüllü vida ile tespit yapılır. Kalkaneoküboid eklem altından $3 \mathrm{~cm}$ 'lik insizyonla Evans kalkaneal osteotomisi yapılır. Iliak kanattan kama ya da allogreft çakılır. Ek olarak tibialis posterior ilerletme uygulanır.

\section{KAYNAKLAR}

1. Günez B. Serebral palsi'de alt ekstremite deformiteleri ve tedavisi, Tıpta Uzmanlık Tezi (Danışman: Dr. Faham Sipahi). Ankara: Gülhane Tıp Fakültesi; 1974.

2. Koca K. Serebral palsili çocuklarda yürüme analizi eşliğinde alt ekstremite deformitelerine yönelik çok seviyeli ortopedik cerrahi tedavi, Tıpta Uzmanlık Tezi (Danışman: Dr. Mustafa Başbozkurt). Ankara: Gülhane Tıp Fakültesi; 2005.

3. Atilla A. Serebral Palsili Hastaların Proksimal Femoral Osteotomilerinde Yeni Bir Tespit: Kilitli Plak Uygulamalarımız, Tıpta Uzmanlık Tezi (Danışman: Dr. Cemil Yıldız). Ankara: Gülhane Tıp Fakültesi; 2010.

4. Menekşeoğlu N. Serebral palsi'li çocuklarda ayak deformitesine yönelik cerrahi tedavi sonuçlarımız, Tıpta Uzmanlık Tezi (Danışman: Dr. Cemil Yıldız). Ankara: Gülhane Tıp Fakültesi; 2014.

5. Akpancar S. Serebral palsili çocuklarda diz fleksiyon deformitesinin tedavisinde kontrollü hemiepifizyodez sonuçlarımız, Tıpta Uzmanlık Tezi (Danışman: Dr. Cemil Yıldız). Ankara: Gülhane Tıp Fakültesi; 2016.
6. Koca K, Yıldız C, YurttaşY, Balaban B, Hazneci B, Bilgiç S, Başbozkurt $M$. Outcomes of combined hamstring release and rectus transfer in children with crouch gait. Ortop Traumatol Rehabil 2009;11:3338. https://pubmed.ncbi.nlm.nih.gov/19828915/

7. Koca K, Yıldız C, Yurttaş Y, Balaban B, Hazneci B, Bilgiç S, Başbozkurt M. Outcomes of multi level orthopedic surgery in children with cerebral palsy. Eklem Hastalık Cerrahisi 2011;22:69-74. https://pubmed.ncbi.nlm.nih.gov/21762060/

8. Yıldız C, Yurttaş Y, Koca K, Atbaşı Z, Atilla A, Başbozkurt M. Kalça deformiteli serebral palsili hastalarda proksimal varus derotasyon osteotomi işleminin yaşam kalitesine etkisi. 22. Ulusal Türk Ortopedi ve Travmatoloji Kongresi, Sözel Bildiriler, S-317; Kasım 2011. p.73.

9. Yıldız C, Atilla A, Koca K, Ege T, Başbozkurt M. Complications with locking pediatric femur plates at osteotomies of patients with cerebral palsy, Combined 33rd SICOT \& 17th PAOA Orthopedic World Conference Abstract Book 2012; Free Paper 33114.

10. Yıldız C. Pediatric Locking Hip Plates: Indications, Techniques. EPOS-BAT Advanced Course: Current Concepts in the Management of Pediatric Hip Disorders 6-7 September 2013. 
11. Yıldız C, Demirkale i. Hip problems in cerebral palsy: screening, diagnosis and treatment. Curr Opin Pediatr 2014;26:85-92. Crossref

12. Pediatrik osteotomi plağında yenilik. T. C. Türk Patent Enstitüsü. Faydalı Model Belgesi, Tescil Numarası: TR 2015 06846. https://portal.turkpatent.gov.tr/anonim/arastirma/ patent/detayli

13. Yıldız C, Koca K, Akpancar S, Tunay S. Serebral Palsili Çocuklardaki Diz Fleksiyon Kontraktüründe Kontrollü Anterior Diz Hemiepifizyodezi Etkili midir? 1. Ulusal Çocuk Ortopedisi Kongresi, SB4; 2016.

14. Yıldız C, Akpancar S, Koca K. Is guided hemiepiphysiodesis with '8 Plate' effective for treatment of fixed knee flexion contracture in patients with cerebral palsy? Dev Med Child Neurol 2017;59:55. Crossref

15. Yıldız C, Elbasan B. Serebral palside diz problemleri. TOTBID Derg 2018;17:510-15. Crossref

16. Yıldız C, Atilla H, Erdem Y. How safe is the transverse osteotomy and nonanatomic reduction with locking plate fixation in proximal osteotomies of cerebral palsied children? American Academy for Cerebral Palsy and Developmental Medicine 72nd Annual Meeting Program Book 2018: SP55. Dev Med Child Neurol 2018:60;109-10. Crossref

17. Yıldız C, Can H, Erdem Y, Sariyilmaz K, Özsezen AM. Kompleks ortopedik problemlerin tedavisinde 3 boyutlu katı modellemenin tedavi sonuçlarına katkısı. 29. Ulusal Türk Ortopedi ve Travmatoloji Kongresi, Poster Bildiriler, GO-1/ PB - 2. 22-29 Ekim 2019. Acta Orthop Traumatol Turc 2019;53 Suppl 1:105. https://www.aott.org.tr/Content/ files/sayilar/368/368-3418.pdf

18. Yıldız C. Planovalgus ayak. Çocuk Ortopedisi Derneği, II. Serebral Palsi Sempozyumu, 11-12 Mayıs 2019, İstanbul.

19. Sees JP, Truong WH, Novacheck TF, Miller F, Georgiadis A. What's New in the Orthopaedic Treatment of Ambulatory Children With Cerebral Palsy Using Gait Analysis. J Pediatr Orthop 2020;40:e498-503. Crossref

20. Rehbein I, Teske V, Pagano I, Cúneo A, Pérez M, von Heideken $\mathrm{J}$. Analysis of orthopedic surgical procedures in children with cerebral palsy. World J Orthop 2020;11:222-31. Crossref

21. Novak I, Morgan C, Fahey M, Finch-Edmondson M, Galea C, Hines A, Langdon K, McNamara M, Paton MCB, Popat $H$, Shore B, Khamis A, Stanton E, Finemore OP, Tricks A, te Velde A, Dark L, Morton N, Badawi N. State of the Evidence Traffic Lights 2019: Systematic Review of Interventions for Preventing and Treating Children with Cerebral Palsy. Curr Neurol Neurosci Rep 2020;20:3. Crossref

22. Amirmudin NA, Lavelle G, Theologis $T$, Thompson N, Ryan JM. Multi level Surgery for Children With Cerebral Palsy: A Meta-analysis. Pediatrics 2019;143:e20183390. Crossref

23. Jones M, Gardner R, Pyman J, Gargan M, Witherow P, Monsell F. Long-term Outcomes Following Multilevel Surgery in Cerebral Palsy. J Pediatr Orthop 2020;40:351-6. Crossref

24. Wild DL, Stegink-Jansen CW, Baker CP, Carmichael KD, Yngve DA. Minimally Invasive SPML Surgery for Children with Cerebral Palsy: Program Development. Minim Invasive Surg Volume 2020;5124952. Crossref

25. Shrader MW, Wimberly L, Thompson R. Hip Surveillance in Children With Cerebral Palsy. J Am Acad Orthop Surg 2019;27:760-8. Crossref

26. Jon R. Management of Neuromuscular Hip Dysplasia in Children With Cerebral Palsy: Lessons and Challenges. J Pediatr Orthop 2018;38 Suppl 1:S21-8. Crossref
27. Huser A, Mo M, Hosseinzadeh P. Hip Surveillance in Children with Cerebral Palsy. Orthop Clin North Am 2018;49:181-90. Crossref

28. Hsieh HC, Wang TM, Kuo KN, Huang SC, Wu KW, Guided Growth Improves Coxa Valga and Hip Subluxation in Children with Cerebral Palsy. Clin Orthop Relat Res 2019;477:256876. Crossref

29. Angelis S, Vynichakis G, Trellopoulos A, Apostolopoulos A, Filippou A, Salmas M, Chandrinos M, Balfousias T, Palaiodimos L, Kyriazi N, Michelarakis J. Derotational subtrochanteric osteotomy and external fixation for the treatment of neurogenic hip dislocation in children with cerebral palsy: Could this be a viable method of treatment? Cureus 2020:12:e7437. Crossref

30. McCarthy J, Shrader MW, Graham K, Veerkamp M, Brower L, Chambers H, Davids JR, Kay RM, Novacheck TF, Pierz K, Rhodes J, Rutz E, Shilt J, Shore BJ, Theologis T, Van Campenhout A. Establishing surgical indications for hamstring lengthening and femoral derotational osteotomy in ambulatory children with cerebral palsy. J Child Orthop 2020;14:50-7. Crossref

31. Schwartz H, Ries J. Rectus femoris transfer in children with cerebral palsy: comparing a propensity score-matched observational study to a randomized controlled trial. Dev Med Child Neurol 2021:63;196-203. Crossref

32. Morais F, Fujino M, Blumetti F, dos Santos CA, Kawamura CM, Ramos BCA, Lopes JAF. Comparison between semitendinosus transfer to distal femur and medial hamstrings surgical lengthening for treatment of flexed knee gait in cerebral palsy. J Orthop Surg 2020;28:1-7. Crossref

33. Kim DW, Kim HW, Yoon JY, Rhee I, Oh MK, Park KB. Endoscopic Transverse Gastrocsoleus Recession in Children With Cerebral Palsy. Front Pediatr 2020;8-12. Crossref

34. Long JT, Laron D, Garcia MC, McCarthy JJ. Screw Anterior Distal Femoral Hemiepiphysiodesis in Children With Cerebral Palsy and Knee Flexion Contractures: A Retrospective Casecontrol Study. J Pediatr Orthop 2020;40:e873-9. Crossref

35. Livingston $\mathrm{MH}$, Walton JM, Cohen E. Surgery for children with disabilities: not without risk. Dev Med Child Neurol 2021;63:130. Crossref

36. Nazareth A, Rethlefsen S, Sousa TC, Mueske NM, Wren TAL, Kay RM. Percutaneous Hamstring Lengthening Surgery is as Effective as Open Lengthening in Children With Cerebral Palsy. J Pediatr Orthop 2019;39:366-71. Crossref

37. Long JT, Cobb L, Garcia MC, McCarthy JJ. Improved Clinical and Functional Outcomes in Crouch Gait Following Minimally Invasive Hamstring Lengthening and Serial Casting in Children With Cerebral Palsy. J Pediatr Orthop 2020;40:e510-5. Crossref

38. Rethlefsen SA, Hanson AM, Wren TAL, Abousamra O, Kay RM. Anterior distal femoral hemiepiphysiodesis with and without patellar tendon shortening for fixed knee flexion contractures in children with cerebral palsy. J Child Orthop 2020;14:415-20. Crossref

39. Aly AS, Rahman AFA, Mahmoud S. Double calcaneal osteotomy in treatment of flexible planovalgus foot deformity in ambulatory cerebral palsy. A case series study. Foot Ankle Surg 2019;25:640-5. Crossref 